\title{
Article \\ Cerium-Promoted Ginsenosides Accumulation by Regulating Endogenous Methyl Jasmonate Biosynthesis in Hairy Roots of Panax ginseng
}

\author{
Ru Zhang ${ }^{1,2,3, *}$, Shiquan Tan ${ }^{1}$, Bianling Zhang ${ }^{1}$, Pengcheng Hu ${ }^{1}$ and Ling Li ${ }^{1}$ \\ 1 Hunan Institute of Engineering, College of Materials and Chemical Engineering, Xiangtan 411104, China; \\ tanshiquan11@163.com (S.T.); blzhang369@163.com (B.Z.); hpc2211899409@163.com (P.H.); \\ liling20180119@126.com (L.L.) \\ 2 Hunan Provincial Key Laboratory of Environmental Catalysis and Waste Recycling, \\ Hunan Institute of Engineering, Xiangtan 411104, China \\ 3 Hunan International Joint Laboratory of Animal Intestinal Ecology and Health, College of Life Sciences, \\ Hunan Normal University, Changsha 410081, China \\ * Correspondence: zhangru2002@hnie.edu.cn; Tel.: +86-731-5868-0016
}

\section{check for} updates

Citation: Zhang, R.; Tan, S.; Zhang, B.; Hu, P.; Li, L. Cerium-Promoted Ginsenosides Accumulation by Regulating Endogenous Methyl Jasmonate Biosynthesis in Hairy Roots of Panax ginseng. Molecules 2021, 26, 5623. https://doi.org/10.3390/ molecules 26185623

Academic Editors: Yi Wang and Xingxian Zhang

Received: 27 July 2021

Accepted: 14 September 2021

Published: 16 September 2021

Publisher's Note: MDPI stays neutral with regard to jurisdictional claims in published maps and institutional affiliations.

Copyright: (c) 2021 by the authors. Licensee MDPI, Basel, Switzerland. This article is an open access article distributed under the terms and conditions of the Creative Commons Attribution (CC BY) license (https:// creativecommons.org/licenses/by/ $4.0 /)$.

\begin{abstract}
Among rare earth elements, cerium has the unique ability of regulating the growth of plant cells and the biosynthesis of metabolites at different stages of plant development. The signal pathways of $\mathrm{Ce}^{3+}$-mediated ginsenosides biosynthesis in ginseng hairy roots were investigated. At a low concentration, $\mathrm{Ce}^{3+}$ improved the elongation and biomass of hairy roots. The $\mathrm{Ce}^{3+}$-induced accumulation of ginsenosides showed a high correlation with the reactive oxygen species (ROS), as well as the biosynthesis of endogenous methyl jasmonate (MeJA) and ginsenoside key enzyme genes (PgSS, PgSE and PgDDS). At a Ce ${ }^{3+}$ concentration of $20 \mathrm{mg} \mathrm{L}^{-1}$, the total ginsenoside content was 1.7-fold, and the total ginsenosides yield was 2.7-fold that of the control. Malondialdehyde (MDA) content and the ROS production rate were significantly higher than those of the control. The activity of superoxide dismutase (SOD) was significantly activated within the $\mathrm{Ce}^{3+}$ concentration range of 10 to $30 \mathrm{mg} \mathrm{L}^{-1}$. The activity of catalase (CAT) and peroxidase (POD) strengthened with the increasing concentration of $\mathrm{Ce}^{3+}$ in the range of $20-40 \mathrm{mg} \mathrm{L}^{-1}$. The $\mathrm{Ce}^{3+}$ exposure induced transient production of superoxide anion $\left(\mathrm{O}_{2}{ }^{\bullet-}\right)$ and hydrogen peroxide $\left(\mathrm{H}_{2} \mathrm{O}_{2}\right)$. Together with the increase in the intracellular MeJA level and enzyme activity for lipoxygenase (LOX), there was an increase in the gene expression level of MeJA biosynthesis including PgLOX, PgAOS and PgJMT. Our results also revealed that $\mathrm{Ce}^{3+}$ did not directly influence $P g S S, P g S E$ and $P g D D S$ activity. We speculated that $\mathrm{Ce}^{3+}$-induced ROS production could enhance the accumulation of ginsenosides in ginseng hairy roots via the direct stimulation of enzyme genes for MeJA biosynthesis. This study demonstrates a potential approach for understanding and improving ginsenoside biosynthesis that is regulated by $\mathrm{Ce}^{3+}$-mediated signal transduction.
\end{abstract}

Keywords: cerium; oxidative stress; reactive oxygen species; MeJA; Panax ginseng; ginsenosides

\section{Introduction}

For thousands of years, Panax ginseng has been one of the most valued herbal medicines in oriental countries [1]. The major active ingredients of ginseng are ginsenosides, polysaccharides, peptides and phenolic compounds, which have been proven to possess important clinical effects [2-5]. Because the cultivation period of ginseng is long and the active ingredients mainly accumulate in aged roots, it is sensible to efficiently culture ginseng cells or tissues in high yield [6,7]. However, ginsenoside accumulation is the result of ginseng's long-term interaction with the environment, and the cultivation of ginseng is susceptible to environmental stresses, nutrients, etc., during the growth of ginseng.

Rare earth elements (REEs) denote a group of 17 metallic elements with similar chemical properties. It has been reported that REEs have important regulatory effects on plant 
physiology $[8,9]$. An appropriate amount of REEs not only promotes the photosynthesis rate, root development and increase in biomass, but also improves plant resistance against stress by altering the activities of some antioxidant enzymes, such as superoxide dismutase (SOD), catalase (CAT) and peroxidase (POD) $[10,11]$. For example, trivalent lanthanum $\left(\mathrm{La}^{3+}\right)$ protects soybean plants from oxidative stress by regulating reactive oxygen species (ROS) or improving their defense ability mediated by the antioxidant system [12]. $\mathrm{La}^{3+}$ also alleviates the oxidative damage induced by UV-B radiation through the reduction of $\mathrm{H}_{2} \mathrm{O}_{2}$ and $\mathrm{O}_{2}{ }^{\bullet-}$ content $[12,13]$. Furthermore, trivalent cerium $\left(\mathrm{Ce}^{3+}\right)$ in an appropriate concentration could enhance the defense system as well as increase the length, number and volume of the root, leading to higher fresh and dry weights of the root and shoot $[8,14]$. $\mathrm{Ce}^{3+}$ can also stimulate flavonoid biosynthesis by inducing PAL activity, which triggers oxidative defense responses in Tetrastigma hemsleyanum suspension cells [15]. It was reported that $\mathrm{La}^{3+}$ and $\mathrm{Ce}^{3+}$ can accelerate the regeneration of Anoectochilus roxburghii cultured in vitro [16]. Furthermore, the rooting rate and root length of peach plantlets could be increased through growth in a $\mathrm{Ce}^{3+}$-supplied medium [17]. All the results show that at optimized conditions, $\mathrm{Ce}^{3+}$ can promote plant growth and physiological properties in tissue or callus culture.

Under environmental stimuli, there is a generation of ROS, including hydrogen peroxide $\left(\mathrm{H}_{2} \mathrm{O}_{2}\right)$, superoxide anion $\left(\mathrm{O}_{2}{ }^{\bullet-}\right)$, singlet oxygen $\left({ }^{\bullet} \mathrm{O}_{2}\right)$ and hydroxyl radical $\left(\mathrm{OH}^{\bullet}\right)$, in plant cells $[18,19]$. Moreover, ROS can act as a signal molecule in plants and trigger a series of cellular responses. Some enzymatic antioxidants in plants can scavenge ROS for environment adaption [20]. Antioxidant enzymes in ginseng mainly include SOD, CAT, POD and ascorbate peroxidase (APX), which can regulate ROS levels in fluctuating environments $[18,21]$. It was reported that ROS and antioxidant enzymes related to oxidative stress could be coupled with the accumulation of ginsenosides in OGA-induced ginseng cells or MeJA-treated ginseng adventitious roots [22-24]. Linoleic acid, a precursor of jasmonates (JAs) biosynthesis that stimulates the activities of SOD, CAT and APX in ginseng adventitious roots, could act as an indicator of ROS generation under elicitation [25]. Moreover, elevated activities of SOD, POD and APX associated with increased ginsenosides production were found in adventitious roots after elicitation with nitroprusside, a nitric oxide donor [26]. It is probably that ROS may function as signal molecules for the induction of defense genes and thus can stimulate the production of ginsenosides as defense metabolites [27]. However, the related mechanism is still unclear.

It is well known that signal molecules such as JAs can act as pivotal elicitors to induce secondary plant metabolites. In plant culture, using signal components as elicitors has become an effective strategy to produce target secondary metabolites. It has been demonstrated that ROS could act as an oxidative stress molecule to trigger the biosynthesis of JAs [27]. These suggest that if we find a chemical that can appropriately activate ROS production or directly promote endogenous JAs biosynthesis, it may become a promising molecule to enhance the production of secondary plant metabolites. As far as we know, no previous investigation has been performed regarding the effect of cerium application on ginseng tissue or cell culture and the evaluation of phytochemicals in vitro. The mechanisms of secondary metabolites under this condition are not clear. Therefore, this study attempts to investigate the effects of different concentrations of cerium on ginseng growth, environmental adaptability and active ingredients' accumulation in terms of antioxidant defense or ROS regulation.

\section{Results and Discussion}

\subsection{Ginseng Hairy Roots Formation}

The cultivation of hairy roots is an effective method to obtain biologically active compounds and to investigate gene functionalities, especially for slow-growing ginseng plants. As an attractive approach for fast growth, fresh root segments of ginseng maintained in vitro were infected with Agrobacterium rhizogenes A4 (Figure 1A,B). The putative hairy roots appeared after 4 weeks (Figure 1C) and were excised from the explants and cultured in 
a 1/2 MS medium containing cefotaxime at 2-week subculture intervals for further selection. As confirmed by RT-PCR (Figure 1D), the hairy root lines presented normal phenotypic characteristics. All five lines (Figure 1D, lane 1-5) harbored the transcripts of landmark rolB and rolC genes. The results suggest that the ginseng hairy roots were successfully transformed by $A$. rhizogenes A4. In 1/2 MS medium, most of the transformed hairy roots showed vigorous elongation with several lateral roots. Among the five hairy root lines, the line that showed the fastest growth and yielded more lateral roots was cultured on solid (Figure 1E) as well as liquid (Figure 1F) 1/2 MS mediums for further studies.
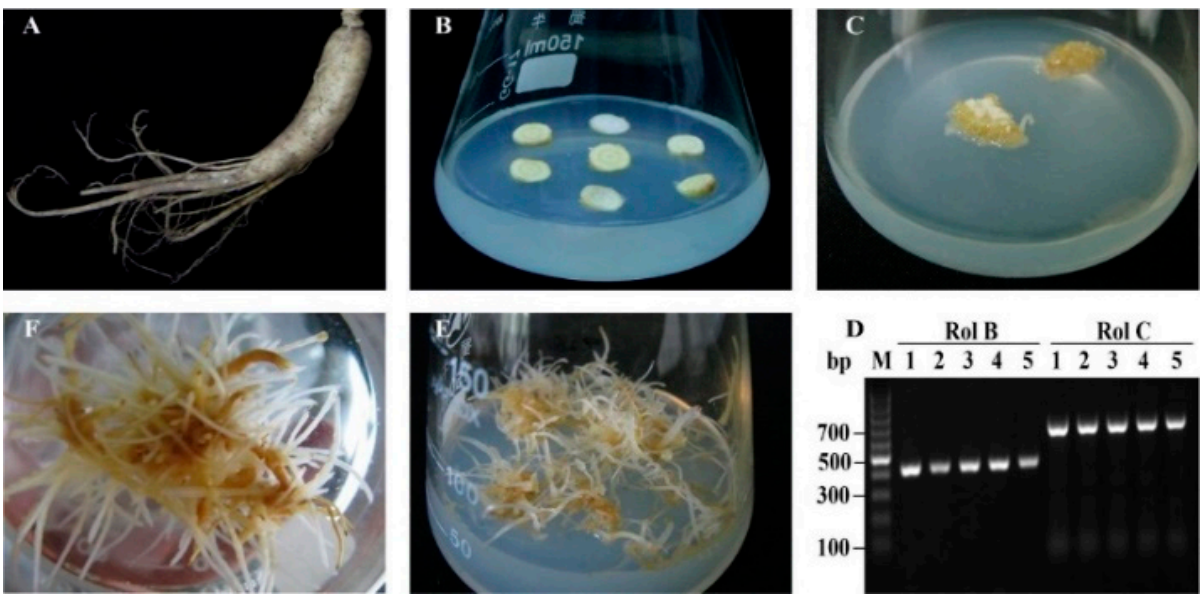

Figure 1. Hairy root induction from $P$. ginseng. (A) Fresh 4-year root of ginseng. (B) Explants from the fresh 4-year root. (C) Putative hairy roots appeared after 4 weeks of culture induced by A. rhizogenes A4. (D) Hairy root lines with normal phenotypic characteristics were confirmed by RT-PCR using the landmark genes rolB and rolC. Screened hairy roots were cultured on solid (E) and liquid (F) $1 / 2$ MS mediums.

\subsection{Growth Index of Ginseng Hairy Roots}

The effect of $\mathrm{Ce}^{3+}$ concentration on morphogenic changes, root elongation, biomass and the growth ratio of ginseng hairy roots are presented in Figure 2 and Table 1 . At $\mathrm{Ce}^{3+}$ concentrations of 5, 10 and $20 \mathrm{mg} \mathrm{L}^{-1}$, the ginseng hairy roots were light yellow, long and branched, whereas at 30 and $40 \mathrm{mg} \mathrm{L}^{-1}$, they were slightly darkened in color, short and fragile. Taking a concentration of $\mathrm{Ce}^{3+}$ of zero as the control, root elongation was the highest at $10 \mathrm{mg} \mathrm{L}^{-1}$ (1.4-fold of control) and the lowest at $40 \mathrm{mg} \mathrm{L}^{-1}$ (0.9-fold of control). To determine the biomass, dry matter content (DMC) and growth ratio (GR), as well as the fresh weight (FW) and dry weight (DW), the hairy roots sampled on the seventh day of $\mathrm{Ce}^{3+}$ treatment were assayed. At a $\mathrm{Ce}^{3+}$ concentration of $10 \mathrm{mg} \mathrm{L}^{-1}, \mathrm{FW}$ and DW were $16.0 \mathrm{~g}$ and $1.7 \mathrm{~g}$, respectively, while GR was 13.9, the highest as depicted in Table 1 . When the $\mathrm{Ce}^{3+}$ concentration was $40 \mathrm{mg} \mathrm{L}^{-1}$, the FW, DW and GR values became the smallest, reduced by $12.0 \%, 12.5 \%$ and $16.3 \%$ compared to the control. It was noted that the DMC value was the highest at a $\mathrm{Ce}^{3+}$ concentration of $20 \mathrm{mg} \mathrm{L}^{-1}$. The GR was the lowest at a $\mathrm{Ce}^{3+}$ concentration of $40 \mathrm{mg} \mathrm{L}^{-1}$, suggesting high matter loss at a high $\mathrm{Ce}^{3+}$ dosage. As a comparison, treatment with $20 \mathrm{mM} \mathrm{H}_{2} \mathrm{O}_{2}$ did not affect the growth of hairy roots, but that with $50 \mathrm{mM} \mathrm{H}_{2} \mathrm{O}_{2}$ not only caused color darkening but also induced negative effects on the elongation of hairy roots and accumulation of biomass. 
A

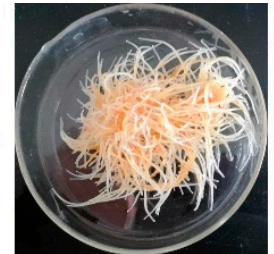

$0 \mathrm{mg} \mathrm{L}^{-1}$

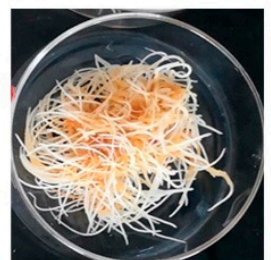

1 d

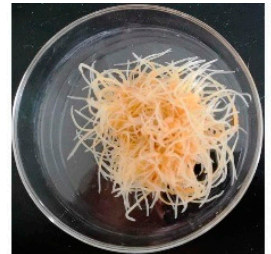

$5 \mathrm{mg} \mathrm{L}^{-1}$

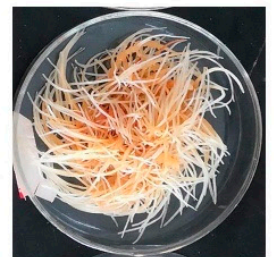

3 d

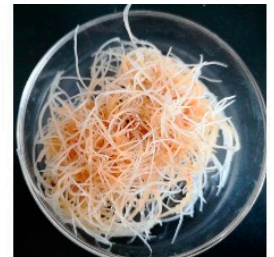

$10 \mathrm{mg} \mathrm{L}^{-1}$

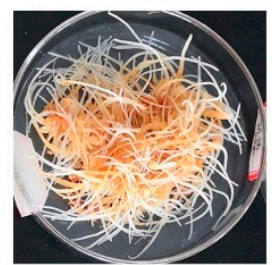

$5 \mathrm{~d}$

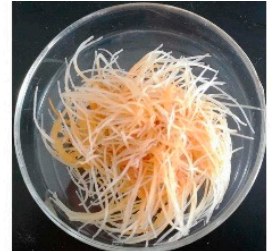

$20 \mathrm{mg} \mathrm{L}^{-1}$

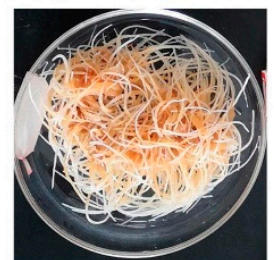

$7 \mathrm{~d}$

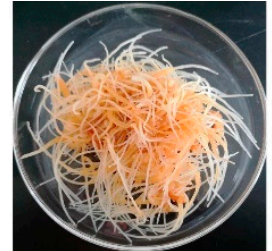

$30 \mathrm{mg} \mathrm{L}^{-1}$

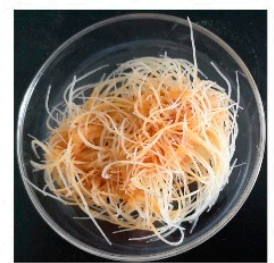

$20 \mathrm{mM}$

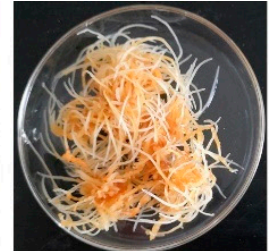

$40 \mathrm{mg} \mathrm{L}^{-1} \mathrm{Ce}^{3+}$

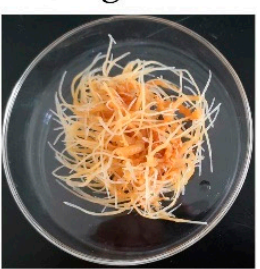

$50 \mathrm{mM}$

\section{B} $20 \mathrm{mg} \mathrm{L}^{-1} \mathrm{Ce}^{3+}$

Figure 2. Growth and morphology of ginseng hairy roots under different treatments. (A) After a preculture period of $21 \mathrm{~d}$, followed by $\mathrm{Ce}^{3+}$ treatment of different concentrations for $7 \mathrm{~d}$ in a liquid $1 / 2 \mathrm{MS}$ medium. (B) After a preculture period of $21 \mathrm{~d}$, followed by $\mathrm{Ce}^{3+}$ treatment of $20 \mathrm{mg} \mathrm{L}^{-1}$ for 1,3,5 and $7 \mathrm{~d}$ in a solid 1/2 MS medium. (C) After a preculture period of $21 \mathrm{~d}$, followed by $\mathrm{H}_{2} \mathrm{O}_{2}$ treatment at different concentrations for $7 \mathrm{~d}$ in a liquid $1 / 2 \mathrm{MS}$ medium.

Table 1. Effect of $\mathrm{Ce}^{3+}$ concentration on the growth of ginseng hairy roots.

\begin{tabular}{|c|c|c|c|c|c|}
\hline \multirow{2}{*}{$\begin{array}{l}\text { Ce Concentration } \\
\mathrm{mg} \mathrm{L}^{-1}\end{array}$} & \multicolumn{5}{|c|}{ Hairy Roots Growth Parameters } \\
\hline & $\begin{array}{l}\text { Average Root } \\
\text { Length (mm) }\end{array}$ & Fresh Weight (g) & Dry Weight (g) & Dry Matter Content (\%) & Growth Ratio \\
\hline 0 & $3.6 \pm 0.1^{\mathrm{a}}$ & $9.2 \pm 0.2^{\mathrm{a}}$ & $0.8 \pm 0.2^{\mathrm{a}}$ & $8.2 \pm 0.3^{a}$ & $8.0 \pm 0.5^{a}$ \\
\hline 5 & $4.0 \pm 0.2^{b}$ & $12.7 \pm 0.3^{b}$ & $1.1 \pm 0.1^{b}$ & $8.4 \pm 0.2^{\mathrm{a}}$ & $11.2 \pm 0.7^{\mathrm{b}}$ \\
\hline 10 & $5.1 \pm 0.2^{c}$ & $16.0 \pm 0.5^{c}$ & $1.7 \pm 0.1^{\mathrm{c}}$ & $10.8 \pm 0.8^{b}$ & $13.9 \pm 0.7^{\mathrm{c}}$ \\
\hline 20 & $5.0 \pm 0.1^{\mathrm{c}}$ & $14.8 \pm 0.6^{\mathrm{d}}$ & $1.6 \pm 0.2^{c}$ & $11.1 \pm 0.9^{b}$ & $13.3 \pm 0.8^{\mathrm{c}}$ \\
\hline 30 & $3.6 \pm 0.2^{\mathrm{a}}$ & $10.7 \pm 0.4^{\mathrm{e}}$ & $1.0 \pm 0.2^{b}$ & $9.6 \pm 0.5^{c}$ & $9.2 \pm 0.6^{\mathrm{d}}$ \\
\hline 40 & $3.4 \pm 0.3^{\mathrm{a}}$ & $8.1 \pm 0.3^{f}$ & $0.7 \pm 0.1^{\mathrm{a}}$ & $8.5 \pm 0.3^{\mathrm{a}}$ & $6.7 \pm 0.5^{\mathrm{e}}$ \\
\hline
\end{tabular}

Data are average values of three replicates \pm standard deviation (SD). Means in each column with the same letters are not significantly $(p<$ 0.05) different based on Duncan's Multiple Range Test.

REEs have been widely applied in plant biotechnology, and an appropriate amount of REEs could have positive effects on callus growth, cell viability, seed germination and root development $[15,16,28,29]$. Our results so far indicate that $\mathrm{Ce}^{3+}$ can significantly affect the metabolic processes of ginseng hairy roots. Treatment of $\mathrm{Ce}^{3+}$ in low concentrations (5-20 mg L ${ }^{-1}$ ) improved the growth of ginseng hairy roots, whereas that in high concentrations (above $30 \mathrm{mg} \mathrm{L}^{-1}$ ) inhibited the growth, partially consistent with reported literature $[8,14,30]$. It was reported that cerium has certain effects on plant growth or physiology. A high concentration of $\mathrm{Ce}^{4+}$ nanoparticles $\left(2000 \mathrm{mg} \mathrm{L}^{-1}\right)$ did not affect radish root elongation [31], whereas $\mathrm{Ce}^{4+}$ nanoparticles at $500 \mathrm{mg} \mathrm{L}^{-1}$ could increase the elongation of the cucumber root and alfalfa stem [32]. Cerium treatment in magnesium-deficient media significantly promoted the activities of key enzymes as well as the contents of amino acids, chlorophyll, soluble proteins and spinach growth [33]. The reports suggest that the promotional effect of cerium could be related to the state of cerium as well as the specificity of plant species and growth environment.

\section{3. $\mathrm{Ce}^{3+}$ Stimulates Ginsenoside Accumulation in Ginseng Hairy Roots}

At present, more than 50 ginsenosides have been isolated and identified from ginseng roots. The major ones are $\mathrm{Rb}_{1}, \mathrm{Rb}_{2}, \mathrm{Rc}, \mathrm{Rd}$, $\mathrm{Re}$ and $\mathrm{Rg}_{1}$, constituting more than $80 \%$ of total ginsenosides. These six ginsenosides can be used as a representative for the analysis of total saponins [34]. As shown in Table 2, the ginsenoside content increased significantly with 
the increase in $\mathrm{Ce}^{3+}$ concentration from 5 to $20 \mathrm{mg} \mathrm{L}^{-1}$, after which ginsenoside content started to decrease. Under the $\mathrm{Ce}^{3+}$ treatment of $20 \mathrm{mg} \mathrm{L}^{-1}$, the content of ginsenoside $\mathrm{Rb}_{1}, \mathrm{Rb}_{2}, \mathrm{Rc}, \mathrm{Rd}, \mathrm{Re}$ and $\mathrm{Rg}_{1}$ increased by 1.7-, 3.4-, 3.3-, 2.1-, 1.4- and 1.2-fold, respectively, compared with the control of a $\mathrm{Ce}^{3+}$ concentration of zero. The total ginsenoside reached $16.4 \mathrm{mg} \mathrm{g}^{-1}$, which is a 1.7-fold increase, giving a total yield 2.7-fold greater than that of the control. Despite the fact that the total ginsenoside content did not change much upon $\mathrm{Ce}^{3+}$ treatment of $30 \mathrm{mg} \mathrm{L}^{-1}$, there was a significant decrease in total yield. It is plausible that $\mathrm{Ce}^{3+}$ inhibited the growth of ginseng hairy roots, resulting in an increase in the relative content of ginsenosides in hairy roots. When the concentration of $\mathrm{Ce}^{3+}$ was $40 \mathrm{mg} \mathrm{L}^{-1}$, the production of ginsenoside decreased drastically, by $7.9 \%$ compared with the control value.

Table 2. Ginsenoside content in ginseng hairy roots under $\mathrm{Ce}^{3+}$ treatment for $7 \mathrm{~d}$ in a $1 / 2 \mathrm{MS}$ medium after preculture of $21 \mathrm{~d}$.

\begin{tabular}{|c|c|c|c|c|c|c|c|c|}
\hline \multirow{2}{*}{$\begin{array}{c}\mathrm{Ce}^{3+} \\
\left(\mathrm{mg} \mathrm{L}^{-1}\right)\end{array}$} & \multicolumn{6}{|c|}{ Ginsenoside (mg/g FW) } & \multirow{2}{*}{ Total Content(mg/g) } & \multirow{2}{*}{$\begin{array}{l}\text { Total Yield } \\
\text { (mg) }\end{array}$} \\
\hline & $\mathbf{R b}_{1}$ & $\mathbf{R b}_{2}$ & $\mathrm{Rc}$ & Rd & $\mathrm{Rg}_{1}$ & $\operatorname{Re}$ & & \\
\hline 0 & $2.2 \pm 0.08^{a}$ & $0.3 \pm 0.01^{a}$ & $0.4 \pm 0.06^{a}$ & $1.9 \pm 0.1^{\mathrm{a}}$ & $2.0 \pm 0.1^{\mathrm{a}}$ & $2.9 \pm 0.1^{a}$ & $9.6 \pm 0.13^{a}$ & $88.7 \pm 2.1^{a}$ \\
\hline 5 & $2.5 \pm 0.07^{\mathrm{a}}$ & $0.4 \pm 0.02^{b}$ & $0.6 \pm 0.08^{b}$ & $2.2 \pm 0.1^{\mathrm{a}}$ & $2.1 \pm 0.1^{\mathrm{a}}$ & $3.1 \pm 0.3^{a}$ & $10.9 \pm 0.4^{\mathrm{a}}$ & $137.8 \pm 5.2^{b}$ \\
\hline 10 & $3.6 \pm 0.2^{b}$ & $0.5 \pm 0.06^{b}$ & $1.3 \pm 0.1^{\mathrm{c}}$ & $3.0 \pm 0.3^{b}$ & $2.6 \pm 0.2^{b}$ & $3.2 \pm 0.4^{b}$ & $14.2 \pm 0.5^{b}$ & $227.6 \pm 8.3^{c}$ \\
\hline 20 & $3.9 \pm 0.3^{b}$ & $0.9 \pm 0.08^{c}$ & $1.4 \pm 0.1^{\mathrm{c}}$ & $3.9 \pm 0.2^{c}$ & $2.8 \pm 0.1^{b}$ & $3.6 \pm 0.3^{b}$ & $16.4 \pm 0.5^{c}$ & $242.2 \pm 5.6^{\mathrm{d}}$ \\
\hline 30 & $3.8 \pm 0.2^{b}$ & $0.8 \pm 0.04^{c}$ & $1.4 \pm 0.1^{\mathrm{c}}$ & $3.6 \pm 0.2^{b}$ & $2.8 \pm 0.3^{b}$ & $3.4 \pm 0.4^{b}$ & $15.8 \pm 0.3^{c}$ & $168.8 \pm 6.4^{\mathrm{e}}$ \\
\hline 40 & $2.0 \pm 0.1^{\mathrm{a}}$ & $0.3 \pm 0.05^{\mathrm{a}}$ & $0.3 \pm 0.06^{\mathrm{a}}$ & $1.9 \pm 0.1^{\mathrm{a}}$ & $2.0 \pm 0.1^{\mathrm{a}}$ & $2.9 \pm 0.3^{a}$ & $10.1 \pm 0.2^{\mathrm{a}}$ & $81.7 \pm 4.2^{\mathrm{a}}$ \\
\hline
\end{tabular}

The data are the average value of three replicates \pm standard deviation (SD). Means in each column with the same letters are not significantly $(p<0.05)$ different based on Duncan's Multiple Range Test.

In fact, studies have revealed that REEs showed various effects on the production of secondary metabolites in plant cultures. $\mathrm{A} \mathrm{Ce}^{3+}$ supplement on the solid culture medium of Saussurea medusa cells not only improved the biomass, but also increased the total flavonoids, and its highest biomass and yield increased by $70 \%$ and $100 \%$ compared to those of the control, respectively [35]. Cerium was found to induce apoptosis and was used as an effective abiotic elicitor to bring about a 5-fold taxol increase in comparison to that of the control [35-37]. A similar study indicated that at low concentrations $(0.1 \mathrm{mM})$, cerium did not affect taxol biosynthesis, but at high concentrations $(1 \mathrm{mM})$, cerium induced apoptosis and taxol biosynthesis in Taxus cuspidate suspension cultures [38]. The addition of cerium $\left(\mathrm{CeO}_{2}\right.$ or $\left.\mathrm{CeCl}_{3}\right)$ to the suspension cells of Catharanthus roseus increased the content of indole alkaloids, ajmalicine or catharanthine [39]. Furthermore, it was reported that low-concentration lanthanum directly induced the key enzyme genes of tanshinone, which resulted in enhanced rosmarinic acid and salvianolic acid B 129\% and 148\% more than the control in the hairy roots of Salvia miltiorrhiza, respectively [40]. Because of the significant promotion effect of cerium on the accumulation of ginsenoside in ginseng hairy roots, it becomes imperative to understand the secondary metabolic response induced by cerium. Furthermore, the results suggest that $\mathrm{Ce}^{3+}$ increases the content of ginsenosides by regulating the biosynthetic metabolic flow of ginsenosides.

\section{4. $\mathrm{Ce}^{3+}$-Induced ROS Production and Antioxidant Enzyme Activities}

ROS accumulation is a hallmark of stress in plants, and $\mathrm{O}_{2}{ }^{\bullet-}, \mathrm{H}_{2} \mathrm{O}_{2}$ and malondialdehyde (MDA) are frequently used as an index of oxidative stress. As shown in Figure 3A, $\mathrm{Ce}^{3+}$ addition (20-40 $\mathrm{mg} \mathrm{L}^{-1}$ ) resulted in a significant increase in $\mathrm{O}_{2}{ }^{--}$content in ginseng hairy roots after $7 \mathrm{~d}$ treatment $(p<0.05)$ and was 1.8 -fold higher at $40 \mathrm{mg} \mathrm{L}^{-1}$ than that of the control. Furthermore, $\mathrm{Ce}^{3+}\left(20-40 \mathrm{mg} \mathrm{L}^{-1}\right)$ rapidly elicited $\mathrm{H}_{2} \mathrm{O}_{2}$ synthesis and released $\mathrm{H}_{2} \mathrm{O}_{2}$ in ginseng hairy roots, which peaked at a Ce ${ }^{3+}$ concentration of $20 \mathrm{mg} \mathrm{L}^{-1}$ (Figure 3B). The response of MDA content to $\mathrm{Ce}^{3+}$ was like that of $\mathrm{H}_{2} \mathrm{O}_{2}$. At a concentration of $20 \mathrm{mg} \mathrm{L}^{-1}, \mathrm{Ce}^{3+}$ contributed to a maximal increase in MDA, which was 3.1-fold higher than that of the control (Figure 3C). 

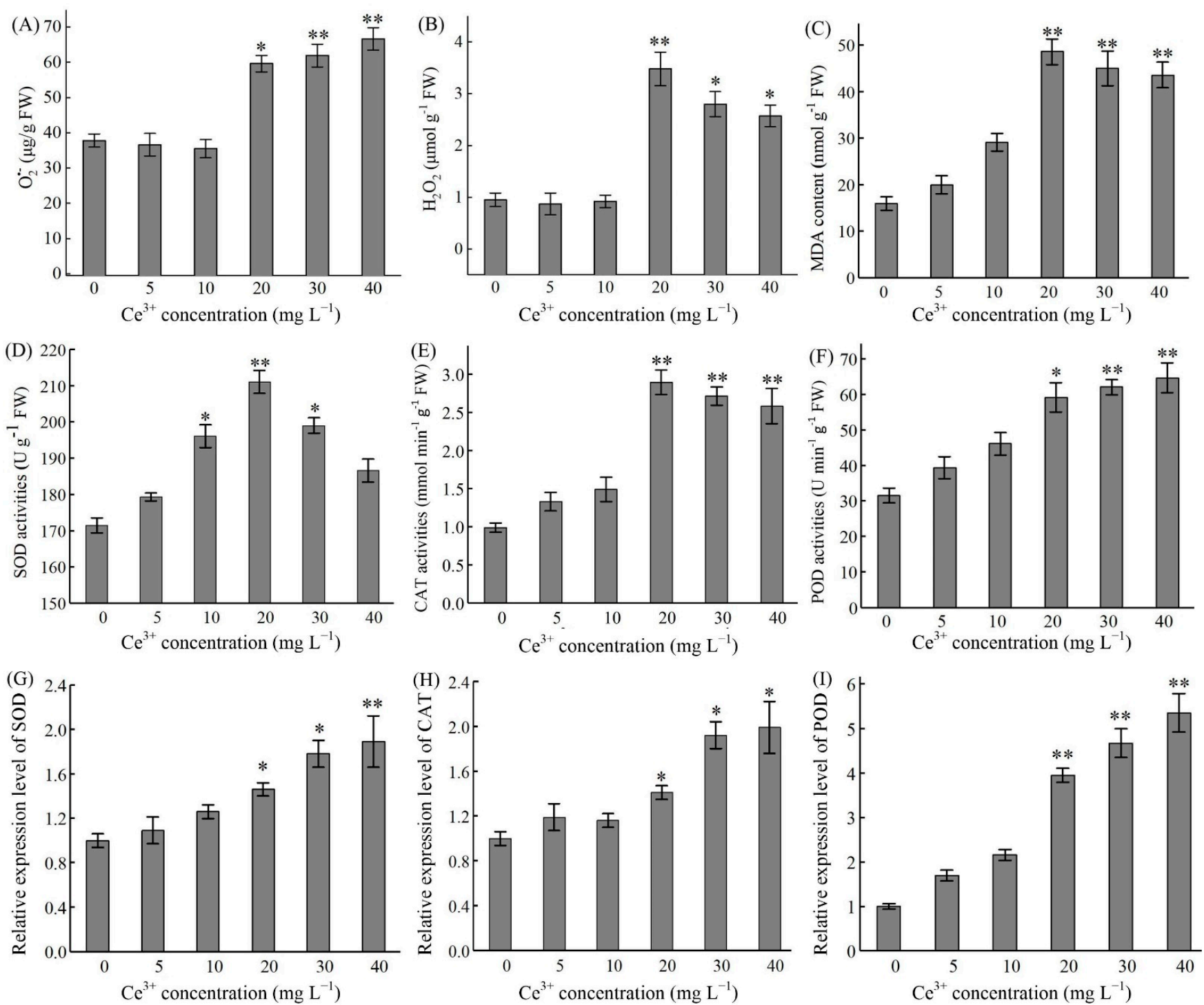

Figure 3. ROS accumulation and antioxidant enzymes activities of ginseng hairy roots upon $\mathrm{Ce}^{3+}$ treatment of $7 \mathrm{~d}$ in a $1 / 2$ MS medium after a $21 \mathrm{~d}$ preculture. (A-C) Content of $\mathrm{O}_{2}{ }^{\bullet-}, \mathrm{H}_{2} \mathrm{O}_{2}$ and MDA. (D-F) Antioxidant enzymes activities of SOD, CAT and POD. (G-I) Relative expression level of SOD, CAT and POD genes. The differences between the treated hairy roots and control hairy roots $(0 \mathrm{~h})$ are statistically significant $\left({ }^{*} p<0.05,{ }^{* *} p<0.01\right)$.

The generation of ROS is a common event in plant stress response, resulting in lipid peroxidation, which could damage the membrane and cause changes to plant growth as well as to metabolic and physiological processes [41,42]. It was found that the positive or negative effects of REEs on the physiological metabolism of plant cells mainly depend on REEs dosage such as in the case of $\mathrm{Ce}^{3+}[43,44]$. High dosages of REEs may cause the generation of ROS and lead to oxidative stress in plant cells [45]. It was reported that $\mathrm{La}^{3+}$ protected soybeans from oxidative stress by reacting with ROS directly or by improving the defense system of plants [12]. In the present study, the growth of ginseng hairy roots was promoted at low or moderate levels of $\mathrm{Ce}^{3+}$ dosage, but at a high dosage of $\mathrm{Ce}^{3+}$, there was a significant promotion of ROS and ginsenoside accumulation. However, a high level of ROS is harmful because the enzymes become less effective for ROS removal and the dynamic balance of ROS in ginseng cells is broken. This conception is consistent with the result of the $\mathrm{Ce}^{3+}$-induced suspension cells of Ginkgo biloba [46]. It is hence considered that an appropriate level of $\mathrm{Ce}^{3+}$ is needed to regulate the accumulation of ROS and secondary metabolism for the healthy and productive growth of ginseng hairy roots. 
To protect cells from the damage of excessive ROS, plants have developed an effective ROS-scavenging system. In the defense mechanisms, SOD, CAT and POD play a major role [46]. We studied the gene expression level and enzyme activity of CAT, SOD and POD in ginseng hairy roots (Figure 3D-I). Upon $\mathrm{Ce}^{3+}$ treatment for $7 \mathrm{~d}$ in a $1 / 2 \mathrm{MS}$ medium after a preculture period of $21 \mathrm{~d}$, there was an obvious increase $(p<0.05)$ of SOD activity in ginseng hairy roots when the $\mathrm{Ce}^{3+}$ concentration was 10 to $30 \mathrm{mg} \mathrm{L}^{-1}$ (Figure 3D). As for CAT and POD activity, they were significant in the $\mathrm{Ce}^{3+}$ concentration range of 20 to $40 \mathrm{mg} \mathrm{L}^{-1} \mathrm{Ce}^{3+}(p<0.05)$ (Figure 3E,F). As expected, the expression levels of the three genes were also induced by $\mathrm{Ce}^{3+}$ in a concentration-dependent manner (Figure 3G-I).

Increased activity of antioxidant enzymes, such as CAT, SOD and POD, has been related to protection from oxidative stress in Pisum sativum and Oryza sativa [47-49]. Ce $\mathrm{e}^{3+}$ treated ginseng hairy roots exhibited a high level of SOD, POD and CAT activities, which could act as circumstantial evidence for its ability to suppress the production of ROS such as $\mathrm{O}_{2}{ }^{--}$and $\mathrm{H}_{2} \mathrm{O}_{2}$. Among antioxidant enzymes, SOD catalyzes the dismutation of $\mathrm{O}_{2}{ }^{\bullet-}$ to $\mathrm{H}_{2} \mathrm{O}_{2}$ while CAT and POD catalyze the conversion of $\mathrm{H}_{2} \mathrm{O}_{2}$ to $\mathrm{H}_{2} \mathrm{O}$ [27]. In the present investigation, $\mathrm{Ce}^{3+}$ in concentrations of $10-30$ and $20-40 \mathrm{mg} \mathrm{L}^{-1}$ enhanced the activities of SOD, CAT and POD in ginseng hairy roots, indicating that at moderate concentrations $\left(20 \mathrm{mg} \mathrm{L}^{-1}\right), \mathrm{Ce}^{3+}$ has advantageous effects on cell growth. At such $\mathrm{Ce}^{3+}$ levels, ginseng hairy roots may change their metabolism from growth to defense through higher antioxidant enzyme activities. The increase in SOD activity means that there is a need in ginseng hairy root cells to convert excessive $\mathrm{O}_{2}{ }^{--}$into $\mathrm{H}_{2} \mathrm{O}_{2}$ upon $\mathrm{Ce}^{3+}$ treatment. The consequent increase in CAT and POD activity might be related to the removal of $\mathrm{H}_{2} \mathrm{O}_{2}$, whose existence is attributable to $\mathrm{Ce}^{3+}$ introduction. Similar mechanisms were suggested in the toxicity studies of $\mathrm{Cd}$ or $\mathrm{Cr}$ on rice [50] and cotton [51]. Overall, the results of the present study indicate that there was activation of protective enzymes in ginseng hairy roots upon ROS production because of $\mathrm{Ce}^{3+}$ stimulation. Maintaining a basal level of ROS by using antioxidant enzyme-mediated dynamic equilibrium, which is above a cytostatic level but below a cytotoxic level, therefore enables proper physiological reactions and the regulation of numerous processes essential for life [19]. We speculate that the ROS generated at a moderate dosage of $\mathrm{Ce}^{3+}$ were partially degraded by antioxidant enzymes and there was an initiation of secondary metabolism.

\section{5. $\mathrm{Ce}^{3+}$-Induced MeJA Accumulation and Its Biosynthesis Key Enzyme Genes Expression}

Jasmonates (JAs) are phytohormones that have essential functions in plants. They are not only involved in the regulation of plant growth and development, but also participate in the response to environmental changes and external stresses [52]. JAs such as JA and MeJA could be highly sensitive to environmental factors. As shown in Figure 4A, there was no significant change in JA content in ginseng hairy roots upon $\mathrm{Ce}^{3+}$ treatments. However, the content of MeJA significantly increased after $\mathrm{Ce}^{3+}$ exposures, reaching a peak at the $\mathrm{Ce}^{3+}$ concentration of $20 \mathrm{mg} \mathrm{L}^{-1}$, corresponding to a 2.1-fold increase in comparison to that of the control $(p<0.05)$. 

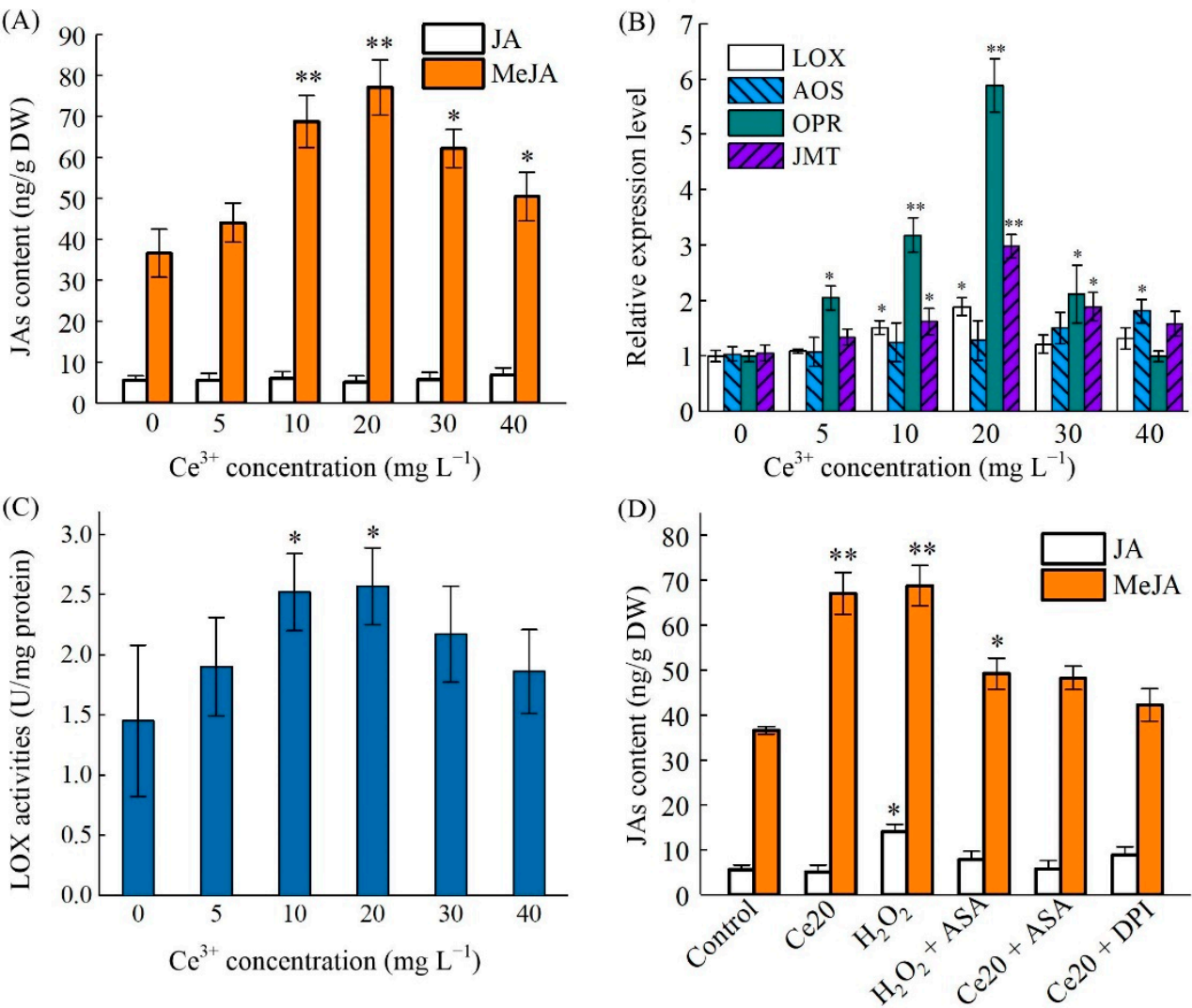

Figure 4. JAs' accumulation and biosynthesis key enzyme genes expression in ginseng hairy roots. (A) JA and MeJA content under different $\mathrm{Ce}^{3+}$ treatments for $48 \mathrm{~h}$ in a $1 / 2 \mathrm{MS}$ medium after a preculture period of $21 \mathrm{~d}$. (B) Expression levels of key enzyme genes of JAs' biosynthesis under different $\mathrm{Ce}^{3+}$ treatments for $48 \mathrm{~h}$ in a $1 / 2 \mathrm{MS}$ medium after a preculture period of $21 \mathrm{~d}$. (C) LOX activities in hairy roots under different $\mathrm{Ce}^{3+}$ treatments in ginseng hairy roots for $48 \mathrm{~h}$ in a $1 / 2 \mathrm{MS}$ medium after a preculture period of $21 \mathrm{~d}$. (D) JA and MeJA content under different treatments in a $1 / 2$ MS medium after a preculture period of $21 \mathrm{~d}$. Control, $\mathrm{Ce} 20$ and $\mathrm{H}_{2} \mathrm{O}_{2}$ represent treatment by $\mathrm{H}_{2} \mathrm{O}, 20 \mathrm{mg} \mathrm{L}^{-1} \mathrm{Ce}^{3+}$ and $20 \mathrm{mM} \mathrm{H}_{2} \mathrm{O}_{2}$ for $48 \mathrm{~h} . \mathrm{H}_{2} \mathrm{O}_{2}+$ ASA, Ce20 + ASA and Ce20 + DPI represent treatment by $20 \mathrm{mM} \mathrm{H}_{2} \mathrm{O}_{2}, 20 \mathrm{mg} \mathrm{L}^{-1} \mathrm{Ce}^{3+}$ for $48 \mathrm{~h}$ and $1 \mathrm{mM}$ ASA or $10 \mu \mathrm{M}$ DPI added to the culture $15 \mathrm{~min}$ before treatment, respectively. The differences between the treated hairy roots and control hairy roots $(0 \mathrm{~h})$ are statistically significant $\left({ }^{*} p<0.05,{ }^{* *} p<0.01\right)$.

To determine whether $\mathrm{Ce}^{3+}$ can affect the expression of genes related to the metabolic pathway of $\alpha$-linolenic acid, which could eventually lead to MeJA biosynthesis, we investigated the expression levels of the related genes, including PgLOX, PgAOS, PgOPR and $P g J M T$. The results indicated that these putative genes were activated and upregulated at different levels of $\mathrm{Ce}^{3+}$ concentration (Figure 4B). Interestingly, the expression levels of $P g O P R$ and $P g J M T$ in the MeJA biosynthesis pathway were the highest after $\mathrm{Ce}^{3+}$ treatment at a concentration of $20 \mathrm{mg} \mathrm{L}^{-1}$, which was highly consistent with the content of endogenous MeJA. The lipoxygenase (LOX) activity of hairy roots was also stimulated by $\mathrm{Ce}^{3+}$ treatment, which followed that of MeJA accumulation and reached a maximum value 2.6-fold greater than that of the control (Figure $4 \mathrm{C}$ ). LOX, one of the key enzymes in JAs' synthesis, plays an important role in JAs' accumulation. It was reported that the PgLOX6 gene from ginseng that encodes a lipoxygenase is responsible for the biosynthesis of JAs and promotion of ginsenosides production through up-regulating the expression of ginsenoside biosynthetic genes [53]. The results showed that LOX activity was activated upon $\mathrm{Ce}^{3+}$ treatment, and there was a significant correlation between LOX activity and MeJA biosynthesis. Studies also confirmed that the rapid accumulation of MeJA in plant cells is related to LOX after wounding [54] and fungal induction [55]. Other 
results also demonstrated that TaOPR2 was involved in the biosynthesis of JA in wheat [56] and that the overexpression of the JMT gene promoted the endogenous MeJA levels in S. miltiorrhiza [57].

The results mentioned above supported the hypothesis that $\mathrm{Ce}^{3+}$ promotes the accumulation of MeJA by inducing the expression of genes related to JAs' biosynthesis. The incursion of external metal ions usually induces oxidative stress to plants, rather than directly stimulating the biosynthesis of secondary metabolites and JAs. To investigate whether there was involvement of $\mathrm{Ce}^{3+}$-induced ROS in JAs' accumulation in ginseng hairy roots, we deployed scavengers or inhibitors in our studies. The ginseng hairy roots were pretreated with $10 \mu \mathrm{M}$ diphenyleneiodonium (DPI, an inhibitor for $\mathrm{O}_{2}{ }^{\bullet-}$ production) or $1 \mathrm{mM}$ ascorbic acid (ASA, a ROS scavenger) before $\mathrm{Ce}^{3+}$ exposure. $\mathrm{H}_{2} \mathrm{O}_{2}(20 \mathrm{mM})$, which is an exogenous ROS, was used as a positive control. As shown in Figure 4D, compared with the control (no treatment), the level of JA in ginseng hairy roots did not change significantly after various treatments except for that of $\mathrm{H}_{2} \mathrm{O}_{2}$. The level of MeJA was induced significantly after the addition of $\mathrm{Ce}^{3+}$ or $\mathrm{H}_{2} \mathrm{O}_{2}$ and obviously suppressed by the $\mathrm{H}_{2} \mathrm{O}_{2}$ scavenger, indicating $\mathrm{H}_{2} \mathrm{O}_{2}$ directly induced the accumulation of MeJA. The production of $\mathrm{O}_{2}{ }^{--}$induced by $\mathrm{Ce}^{3+}$ resulted in an increase in the MeJA level, and such a phenomenon was effectively inhibited by DPI because the reduction of $\mathrm{O}_{2}{ }^{\bullet-}$ limited the production of $\mathrm{H}_{2} \mathrm{O}_{2}$. These results suggest that NADPH oxidase is responsible for the $\mathrm{Ce}^{3+}$-induced production of ROS, and MeJA biosynthesis is dependent on the oxidative burst. In other words, ROS signifies the activation of MeJA accumulation. This is like the mechanism of low-energy ultrasound-induced JA accumulation in Taxus cells [58]. These results have further verified the close relationship of ROS production and JAs' biosynthesis involvement in mediating the elicitation of ginsenoside production in ginseng hairy roots by cerium. The dependence of $\mathrm{Ce}^{3+}$-induced ginsenoside production on JA and ROS production was identified by selective blocking with the corresponding inhibitor and scavenger.

\section{6. $\mathrm{Ce}^{3+}$-Induced PgSS, PgSS, PgDDS Expression and Ginsenosides Biosynthesis}

Ginsenosides belong to triterpene saponins of which biosynthesis is highly regulated by key rate-limiting enzymes, such as $P g S S, P g S E$ and $P g D D S$ [59]. To further reveal how $\mathrm{Ce}^{3+}$-induced ROS promote ginsenoside biosynthesis, the expression level of $P g S S, P g S E$ and $P g D D S$ genes was investigated. As shown in Figure $5 \mathrm{~A}$, when ginseng hairy roots were exposed to $\mathrm{Ce}^{3+}$ at a concentration of $5-40 \mathrm{mg} \mathrm{L}^{-1}$, the expression levels of these three genes changed in a concentration-dependent manner. The expression level of $P g S S$, $P g S E$ and $P g D D S$ reached maximum at a $\mathrm{Ce}^{3+}$ concentration of $20.0 \mathrm{mg} \mathrm{L}^{-1}(p<0.05)$, and were 2.66-, 4.68- and 2.92-fold higher than that of the control, respectively. It is worth pointing out that the expression level of $P g S E$ was still significant at a $\mathrm{Ce}^{3+}$ concentration of $30.0 \mathrm{mg} \mathrm{L}^{-1}$. At a Ce ${ }^{3+}$ concentration of $40.0 \mathrm{mg} \mathrm{L}^{-1}$, however, there was significant inhabitation of all the gene expressions.

Accordingly, the content of PPT-type ginsenosides ( $R e$ and $\mathrm{Rg}_{1}$ ) did not increase significantly after $\mathrm{Ce}^{3+}$ treatment (Figure 5B). After $7 \mathrm{~d}$, the content was $9.08 \mathrm{mg} \mathrm{g}^{-1}$, only 1.34-fold greater than the control (Table 2). However, the content of PPD-type ginsenosides $\left(\mathrm{Rb}_{1}, \mathrm{Rb}_{2}, \mathrm{Rc}\right.$ and $\left.\mathrm{Rd}\right)$ was significantly increased after $\mathrm{Ce}^{3+}$ treatment of $48 \mathrm{~h}$, which was 1.77-, 3.01-, 3.52- and 2.05-fold higher than that of no treatment, respectively. After $48 \mathrm{~h}$ of treatment, the total ginsenoside increased by 1.71-fold, mainly because the change of PPT-type ginsenosides' content was small. 

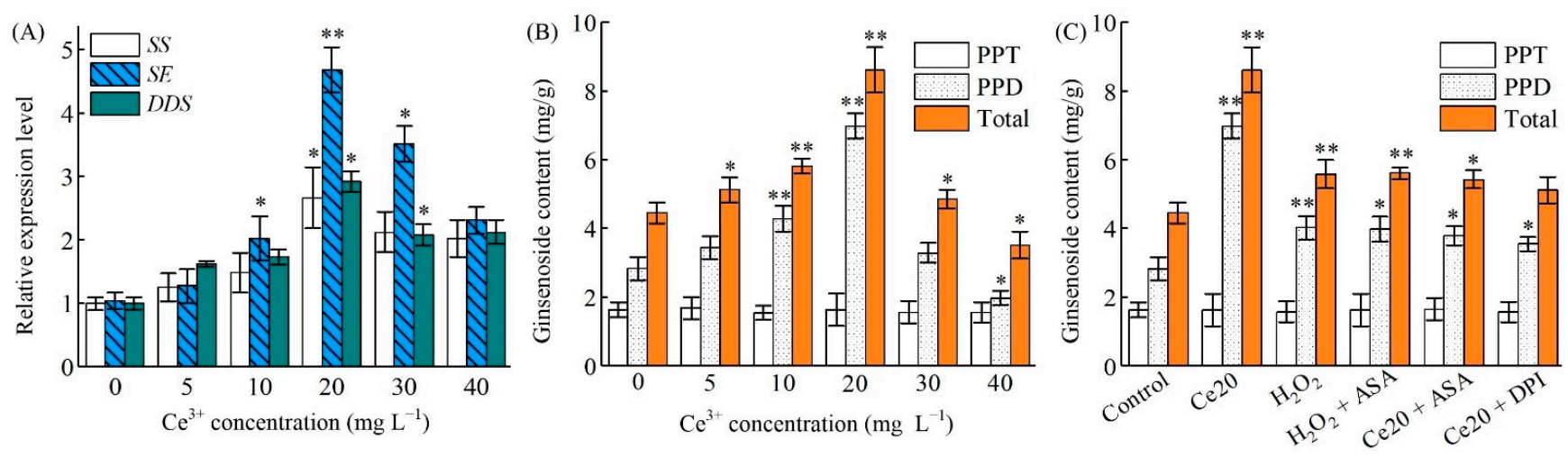

Figure 5. Ginsenosides' accumulation and gene expression of ginseng hairy roots. (A) PPD-, PPT-type and total ginsenoside content under different $\mathrm{Ce}^{3+}$ treatments for $48 \mathrm{~h}$ in a $1 / 2 \mathrm{MS}$ medium after a preculture period of $21 \mathrm{~d}$. (B) Expression level of key enzyme genes of ginsenoside biosynthesis under different $\mathrm{Ce}^{3+}$ treatments for $48 \mathrm{~h}$ in a $1 / 2 \mathrm{MS}$ medium after a preculture period of $21 \mathrm{~d}$. (C) PPD-, PPT-type and total ginsenoside content in hairy roots under different treatments in ginseng hairy roots for $48 \mathrm{~h}$ in a $1 / 2 \mathrm{MS}$ medium after a preculture period of $21 \mathrm{~d}$. Control, Ce20 and $\mathrm{H}_{2} \mathrm{O}_{2}$ represent treatment by $\mathrm{H}_{2} \mathrm{O}, 20 \mathrm{mg} \mathrm{L}^{-1} \mathrm{Ce}^{3+}$ and $20 \mathrm{mM} \mathrm{H}_{2} \mathrm{O}_{2}$ for $48 \mathrm{~h}$, respectively. $\mathrm{H}_{2} \mathrm{O}_{2}+\mathrm{ASA}, \mathrm{Ce} 20+\mathrm{ASA}$ and Ce20 + DPI represent treatment by $20 \mathrm{mM} \mathrm{H}_{2} \mathrm{O}_{2}, 20 \mathrm{mg} \mathrm{L}^{-1} \mathrm{Ce}^{3+}$ for $48 \mathrm{~h}$ and the addition of $1 \mathrm{mM}$ ASA or $10 \mu \mathrm{M}$ DPI to the culture $15 \mathrm{~min}$ before treatment, respectively. The differences between the treated hairy roots and control hairy roots $(0 \mathrm{~h})$ are statistically significant $\left({ }^{*} p<0.05,{ }^{* *} p<0.01\right)$.

In the present study, the results demonstrated that $P g S S$ and $P g S E$ were more sensitive than $P g D D S$ to $\mathrm{Ce}^{3+}$ treatment. This indicates that $\mathrm{Ce}^{3+}$ is inclined to regulate the expression of upstream $P g S S$ and $P g S E$ genes in ginsenosides biosynthesis. Nonetheless, it is impossible to exclude the participation of other important players in this process. JA and its derivatives are known signaling molecules that can induce the biosynthesis of enzymes that are involved in the formation of secondary metabolites in ginseng [60]. Stresses and JAs have been reported to increase the transcript level of $P g S S, P g S E$ and $P g D D S$ [61,62]. Based on the results mentioned so far, one can conclude that the accumulation of $\mathrm{Ce}^{3+}$-mediated ginsenosides is induced by the endogenous MeJA-activated upregulation of transcription of $P g S S, P g S E$ and $P g D D S$. In addition, the expression of these three genes was also induced by incubation of the hairy roots with $\mathrm{H}_{2} \mathrm{O}_{2}$. The inhibitors or scavengers themselves did not affect the transcription of $P g S S, P g S E$ and $P g D D S$ (data not shown). The removal of $\mathrm{H}_{2} \mathrm{O}_{2}$ by ASA or the removal of $\mathrm{O}_{2}{ }^{--}$by DPI would result in the inhabitation of $\mathrm{Ce}^{3+}$-mediated ROS in the transcription of $P g S S, P g S E$ and $P g D D S$ (Figure 5C). The results disclose that the accumulation of JA-mediated ginsenosides in $\mathrm{Ce}^{3+}$-treated ginseng hairy roots is not the only regulation pathway. The proposed model for the regulation of ginsenoside biosynthesis [63] following the ROS-mediated JA signal pathway is illustrated in Figure 6.

It is well known that JA is an important upstream signal for the production of secondary plant metabolites, particularly in the biosynthesis of ginsenosides [60,64]. Environmental stress elevates the level of JA and activates the biosynthesis of nicotine and related pyridine alkaloids in tobacco by up-regulating the expression of genes that catalyzed nicotine formation [65]. The gene expression of key enzymes such as PgSS, PgSE and PgDDS in ginsenoside biosynthesis is related to the content of to-be-catalyzed ginsenosides and is time dependent. Generally, the higher the gene expression level is, the more accumulation of the catalyzed product in the synthesis [66]. The up-regulation of $P g S S, P g S E$ and $P g D D S$ coincided with the biosynthesis of endogenous JA in vanadate-treated ginseng [67]. Our results further imply that the accumulation of $\mathrm{Ce}^{3+}$-induced ginsenosides through ROSinduced JA (especially MeJA) biosynthesis is one of the signal transduction pathways for the regulation of ginsenosides biosynthesis. Whether there are other signaling pathways involved in the regulation of ginsenoside biosynthesis still needs to be further studied. 


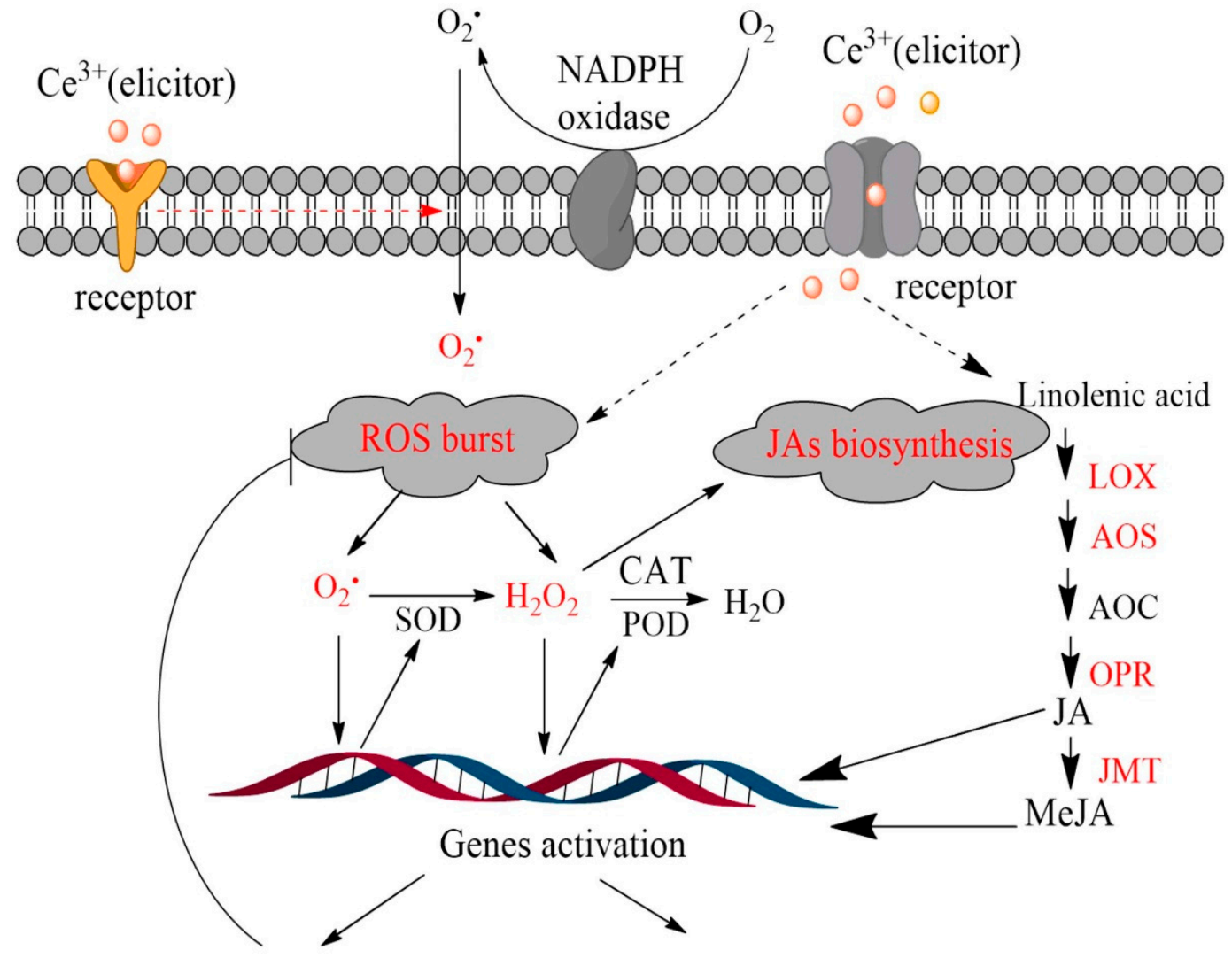

antioxidant enzymes Ginsenosides biosynthesis enzymes

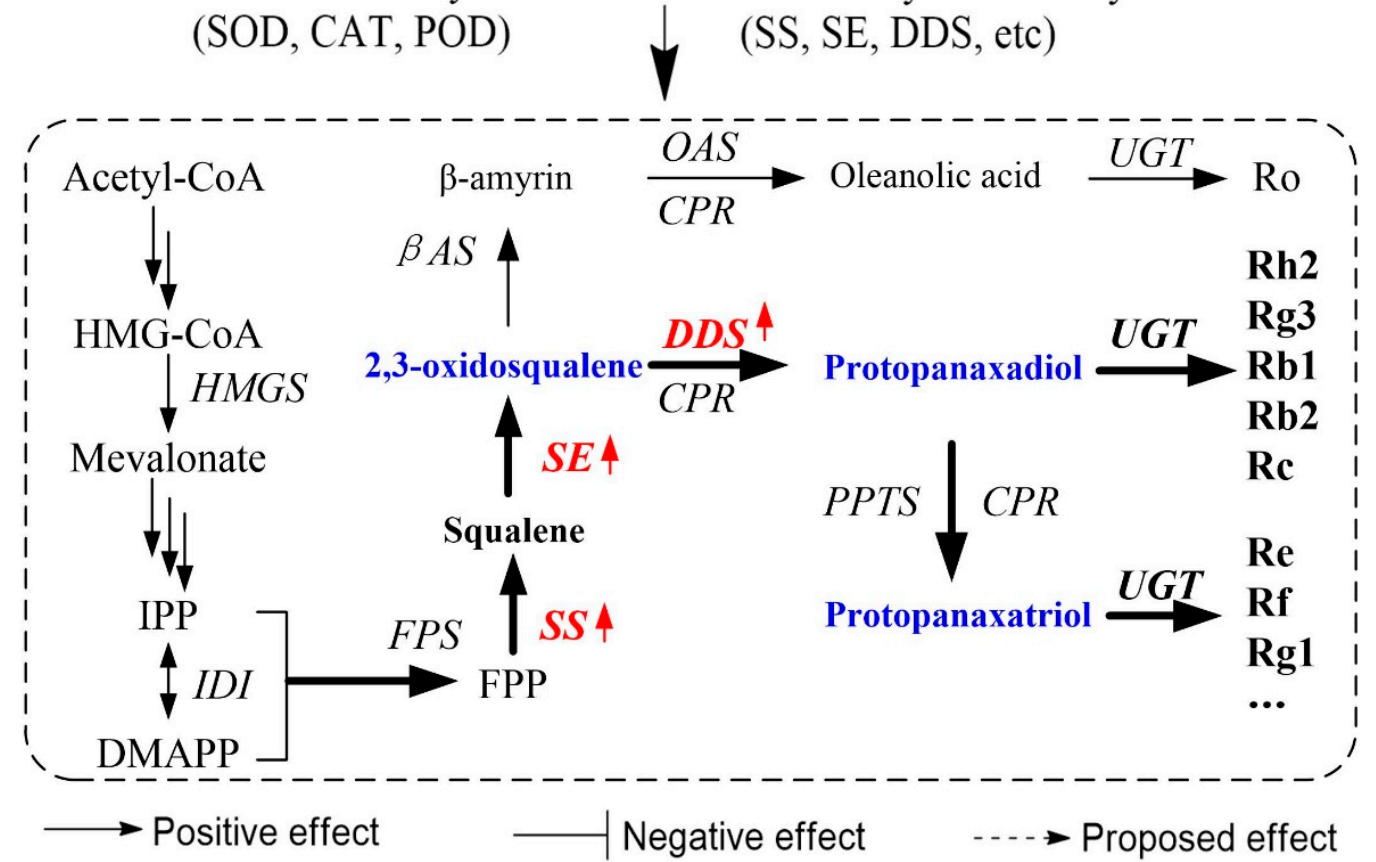

Figure 6. Proposed model for the regulation of ginsenoside biosynthesis following ROS-mediated JAs' signal pathways. (LOX, lipoxygenase; AOS, allene oxide synthase; AOC, allene oxide cyclase; OPR, OPDA reductase 12-oxophyto-dienoic acid reductase; JMT, jasmonate O-methyltransferase; HMGR, 3-hydroxy-3-methylglutaryl-CoA reductase; FPS, farnesyl diphosphate synthase; SS, squalene synthase; SE, squalene epoxidase; $\beta$ AS, $\beta$-amyrin synthase; OAS, oleanolic acid synthase; CPR, cytochrome P450 reductase; DDS, dammarenediol-II synthase; PPDS, protopanaxadiol synthase; and PPTS, protopanaxatriol synthase; UGT, UDP-glycosyltransferase). 


\section{Materials and Methods}

\subsection{Chemicals, Materials and Treatment}

The ginsenoside standards of $\mathrm{Rb}_{1}, \mathrm{Rb}_{2}, \mathrm{Rc}, \mathrm{Rd}, \mathrm{Re}$ and $\mathrm{Rg}_{1}$ purchased from Chengdu Herbpurify (Chengdu, China) were of chromatographic grade. All the other reagents were analytical grade. Four-year fresh ginseng (P. ginseng C.A. Meyer) was collected from Fusong County, Jinlin Province, China. Hairy roots were induced by A. rhizogenes A4 [68]. The ginseng hairy roots for cerium treatment were cultured in flasks containing $1 / 2$ MS liquid medium with an initial inoculation of $1 \mathrm{~g}$ hairy roots at $25^{\circ} \mathrm{C}$ with shaking at $110 \mathrm{rpm}$. After a preculture of $21 \mathrm{~d}$, the hairy roots were treated with cerium of different concentrations for $7 \mathrm{~d}$. A ROS scavenger (ASA) [69], an inhibitor (DPI) of membrane NADPH oxidase and the key enzyme for $\mathrm{O}_{2}{ }^{\bullet-}$ production in the oxidative burst [70] were added to the culture 15 min before Ce treatment. After the treatment, the hairy roots were harvested and frozen in liquid nitrogen for RNA, enzymes, JAs and ginsenosides extraction separately.

\subsection{Determination of Hairy Roots Growth Parameters}

After the preculture and $\mathrm{Ce}^{3+}$ treatment, the morphology and characteristics of ginseng hairy roots including color and length were monitored. The FW and DW of each sample were measured. The GR (in percentage) of each culture was obtained by dividing the difference between the final FW and initial FW by the initial FW. The DMC of each culture was calculated by dividing the final FW by the final DW [71]. The total yield of ginsenosides was calculated by multiplying the total ginsenoside content by the final FW. The hairy roots were separated by filtration and then dried at $60^{\circ} \mathrm{C}$ under vacuum to a constant weight to obtain the dry weight.

\subsection{Determination of Ginsenosides Content}

Ginseng hairy roots were harvested and washed three times with purified water. It was dried to a constant weight at $60^{\circ} \mathrm{C}$ for $48 \mathrm{~h}$. Then, the samples were ground to powder. Ginsenosides were extracted using $80 \%$ methanol at $60^{\circ} \mathrm{C}$ for $1 \mathrm{~h}$ in an ultrasonic bath. After filtration, the extracts were washed with ether, followed by extraction with n-butanol. The butanol layer was evaporated to dryness and dissolved in methanol for analysis [68]. The total ginsenoside was filtered by a $0.22 \mu \mathrm{m}$ membrane filter and analyzed by SHIMADZU LCMS-8050 at $203 \mathrm{~nm}$ with a ZORBAX SB-C18 column $(3.5 \mu \mathrm{m}, 2.1 \mathrm{~mm} \times 150 \mathrm{~mm})$. The mobile phase consisted of acetonitrile (A) and water (B), and the elute program was as follows: A:B (20:80) for $5 \mathrm{~min}$; A:B (20:80) to (38:62) for 5-40 min; A:B (38:62) to (99:1) for 40-42 min; A:B (99:1) for 42-45 min; A:B (21:79) for 46-56 min [72]. The flow rate was $0.5 \mathrm{~mL} / \mathrm{min}$. $\mathrm{Rb}_{1}, \mathrm{Rb}_{2}, \mathrm{Rc}, \mathrm{Rd}, \mathrm{Re}$ and $\mathrm{Rg}_{1}$ were used as standards. Total ginsenoside was the sum of the ginsenoside components. All the HPLC analyses were performed in triplicate.

The samples were analyzed using an Agilent 6420 triple quadrupole mass spectrometer equipped with an electrospray ionization source. LC-MS analyses were performed in the negative ion mode by a full scan. High-purity nitrogen was used as drying gas $(11 \mathrm{~L} / \mathrm{min})$ and nebulizer gas $(15 \mathrm{psi})$ spray voltage $(4000 \mathrm{~V})$. The atomizing temperature was $300^{\circ} \mathrm{C}[73]$.

\subsection{Determination of $\mathrm{O}_{2}{ }^{\bullet-}, \mathrm{H}_{2} \mathrm{O}_{2}$ and $\mathrm{MDA}$}

The content of $\mathrm{O}_{2}{ }^{\bullet-}, \mathrm{H}_{2} \mathrm{O}_{2}$ and MDA was determined as described before [49]. The content of $\mathrm{O}_{2}{ }^{\bullet-}$ was measured by monitoring the nitrite formation from hydroxylamine in the presence of $\mathrm{O}_{2}{ }^{\bullet-}$. The results were shown based on the change of absorbance at $480 \mathrm{~nm} \mathrm{~min}{ }^{-1} \mathrm{~g}^{-1}$ fresh weight. The content of $\mathrm{H}_{2} \mathrm{O}_{2}$ was measured using the Ti( $\left(\mathrm{SO}_{4}\right)_{2}$ method at $410 \mathrm{~nm}$. The MDA content was assayed by the thiobarbituric acid (TBA) reaction at $532 \mathrm{~nm}$ and $600 \mathrm{~nm}$ at $25^{\circ} \mathrm{C}$. 


\subsection{Extraction and Assay of Enzyme}

The total protein was extracted from ginseng hairy roots as described earlier [74] with slight modification. The fresh ginseng hairy roots were harvested and ground at room temperature after $7 \mathrm{~d}$ treatment with $\mathrm{Ce}^{3+}$, and then suspended in extraction buffer containing $50 \mathrm{mM}$ Tris- $\mathrm{HCl}$ (pH7.4), $150 \mathrm{mM} \mathrm{NaCl}, 0.1 \%(v / v)$ Nonidet P-40 and $1 \mathrm{mM}$ PMSF. The homogenate was centrifuged at $4{ }^{\circ} \mathrm{C}, 5000 \mathrm{rpm}$ for $10 \mathrm{~min}$ and the supernatant was collected for determination of the protein concentration using the Enhanced BCA Protein Assay Kit (Beyotime). The activities of SOD, CAT and POD were assayed using commercial kits purchased from the Nanjing Jiancheng Bioengineering Institute (Nanjing, China) [75]. Briefly, the SOD activity was determined by measuring the inhibiting rate of the enzyme to $\mathrm{H}_{2} \mathrm{O}_{2}$ produced by the xanthine morpholine with xanthine oxidase at $550 \mathrm{~nm}$. The CAT activity was measured by the decrease in absorbance at $405 \mathrm{~nm}$ due to the decomposition of $\mathrm{H}_{2} \mathrm{O}_{2}$. The POD activity was measured based on the change of absorbance at $420 \mathrm{~nm}$ during the catalytic action of $\mathrm{H}_{2} \mathrm{O}_{2}$. Enzyme activities were detected using a UV-vis spectrophotometer (TU-1901, Persee, Beijing, China) at $25^{\circ} \mathrm{C}$. LOX activity was determined by measuring the formation of 13(S)-hydro-peroxylinolenic acid (HPLA) at $25{ }^{\circ} \mathrm{C}$, using linolenic acid as the substrate $[58,76]$.

\subsection{Measurement of JAs Level}

JAs' (JA and MeJA) levels were determined by Convinced-test Technology Co., Ltd. (Nanjing, China) using HPLC-MS/MS with slight modification [77]. Approximately $1 \mathrm{~g}$ of fresh ginseng hairy roots was ground to a powder in a pre-cooled mortar. JAs was extracted using $10 \mathrm{~mL}$ of isopropanol at $4{ }^{\circ} \mathrm{C}$ for $60 \mathrm{~min}$. After filtration and with an equal volume of dichloromethane, the extract was shaken for $30 \mathrm{~min}$ and centrifuged at 12,000 rpm for 5 min at $4{ }^{\circ} \mathrm{C}$. The lower layer was evaporated to dryness under $\mathrm{N}_{2}$ and dissolved in methanol ( $0.1 \%$ formic acid) for analysis. The sample was filtered by a $0.22 \mu \mathrm{m}$ membrane filter and analyzed by HPLC-MS/MS. HPLC analysis was performed using an Agilent ZORBAX SB- $\mathrm{C}_{18}$ column $(3.5 \mu \mathrm{m}, 2.1 \mathrm{~mm} \times 150 \mathrm{~mm})$, eluted with solvent A consisting of methanol $-0.1 \%$ formic acid and solvent $B$ consisting of ultrapure water $/ 0.1 \%$ formic acid as the mobile phase at 45:55 $(v / v)$. MS conditions were as follows: The spray voltage was $4500 \mathrm{~V}$; the pressure of aux gas, nebulizer and air curtain was 70, 65 and 15 psi, respectively; and the atomizing temperature was $400{ }^{\circ} \mathrm{C}$.

\subsection{Genes Expression Analysis of Antioxidant Enzymes, Key Enzymes of JAs and Ginsenosides Biosynthesis}

The expression levels of antioxidant enzyme genes including $P g S O D, P g C A T$ and $P g P O D$, key enzyme genes of JAs' biosynthesis including PgLOX, PgAOS, PgOPR and $P g J M T$ and key enzyme genes of ginsenoside biosynthesis including PgSS, PgSE and $P g D D S$ were quantified by qRT-PCR using the SYBR Green stains on the Mini Opticon real-time system (Bio-Rad, Hercules, CA, USA). Total RNA was extracted from ginseng hairy roots using Plant RNA Kit (Omega, Doraville, GA, USA). Reverse transcription was performed using HiFiScript gDNA Removal RT MasterMix (CoWin Biotech Co. Ltd., Beijing, China). The relative expression level was shown after normalization with $\beta$-actin and calculated using the formula $2^{-\Delta \Delta \mathrm{Ct}}$ [74]. All qRT-PCR reactions were performed in triplicate. The primers are listed in Table 3. 
Table 3. Primers of the selected genes verified by qRT-PCR analysis.

\begin{tabular}{|c|c|c|}
\hline Gene & Primer & Sequence $\left(5^{\prime} \rightarrow 3^{\prime}\right)$ \\
\hline \multirow{2}{*}{$P g S O D$} & Forward & CTAAACCССТCACCGTCGTC \\
\hline & Reverse & TTCACTGTAGTTGGGCCGTC \\
\hline \multirow{2}{*}{$P g C A T$} & Forward & AGATACCGGACTTTTGCGCC \\
\hline & Reverse & GACACCCATATGCTGCGGAT \\
\hline \multirow{2}{*}{$P g P O D$} & Forward & GGATTCTTCCACCGCTCCAA \\
\hline & Reverse & CCTTTGTCGGCGAACGTTTT \\
\hline \multirow{2}{*}{$P g L O X$} & Forward & CGTGGTGGACAGAAATCCGA \\
\hline & Reverse & TTGAGGGGTTTTGAGGACGG \\
\hline \multirow{2}{*}{ PgAOS } & Forward & CTGCAGGTGGAATTAGCGGA \\
\hline & Reverse & CATCCGGAGCGATTCGTACA \\
\hline \multirow{2}{*}{$P g O P R$} & Forward & GATGGCTCTAGCGTTGCAGA \\
\hline & Reverse & TGACTGTTAACACCTACCGGC \\
\hline \multirow{2}{*}{$P g J M T$} & Forward & ACAGGAGGCCGAATGGTTTT \\
\hline & Reverse & CCTTAAGGGCGACGGCTAAT \\
\hline \multirow{2}{*}{ PgSS } & Forward & TAGGCATGCGGAAAAGCAGA \\
\hline & Reverse & TGTTGAATGACGAGGCCGAA \\
\hline \multirow{2}{*}{$\operatorname{PgSE}$} & Forward & TCGCGATCTTCTTAGGCCAC \\
\hline & Reverse & CCACTGGCTTGCGTAATGTG \\
\hline \multirow{2}{*}{$\operatorname{PgDDS}$} & Forward & CCCTGCAGTGCCTACTGTTA \\
\hline & Reverse & СТСССАAACTGCGAAACCAC \\
\hline \multirow{2}{*}{ RolB } & Forward & GCTCTTGCAGTGCTAGATTT \\
\hline & Reverse & GAAGGTGCAAGCTACCTCTC \\
\hline \multirow{2}{*}{ RolC } & Forward & CTCCTGACATCAAACTCGTC \\
\hline & Reverse & TGCTTCGAGTTATGGGTACA \\
\hline \multirow{2}{*}{$\beta$-actin } & Forward & TGCCCCAGAAGAGCACCCTGT \\
\hline & Reverse & AGCATACAGGGAAAGATCGGCTTGA \\
\hline
\end{tabular}

\subsection{Statistical Analysis}

The results were presented as mean \pm standard deviation (SD) values of three replicates. All the data were statistically analyzed by one-way analysis of variance (ANOVA) with SPSS (version 17.0, Chicago, IL, USA), followed by the Duncan test. A $p$-value of less than 0.05 was regarded as significant.

\section{Conclusions}

The culture of hairy roots is a promising alternative to improve the production of target secondary metabolites through various elicitors or precursors supplemented in the media. The present study provides the first evidence that the optimized use of $\mathrm{Ce}^{3+}$ on a 1/2 MS medium can act as an effective elicitor to enhance the biosynthesis of pharmaceutically active ginsenosides in hairy root cultures of $P$. ginseng. The main mechanism is that $\mathrm{Ce}^{3+}$ activates the biosynthesis of ROS-mediated endogenous MeJA, which induces the accumulation of ginsenosides. Meanwhile, the presence of $\mathrm{Ce}^{3+}$ in a concentration of $10 \mathrm{mg} \mathrm{L}^{-1}$ in the culture medium resulted in high growth of hairy roots and biomass accumulation, and a concentration of $20 \mathrm{mg} \mathrm{L}^{-1}$ resulted in a high yield of ginsenosides. For in vitro production of medicinal herbs with efficacy, the growth parameters and biomass accumulation should be coupled with the efficient biosynthesis of active constituents. It is demonstrated that the proper use of $\mathrm{Ce}^{3+}$ can lead to improvements in both growth indices and the yield of valuable active compounds in the culture of $P$. ginseng hairy roots.

Author Contributions: Conceptualization, R.Z.; methodology, S.T., B.Z., P.H. and L.L.; validation, S.T. and R.Z.; data analysis: R.Z. and B.Z.; investigation, S.T., B.Z., P.H. and L.L.; writing-review and editing: R.Z. and B.Z.; supervision: R.Z. and B.Z.; funding acquisition, R.Z. All authors have read and agreed to the published version of the manuscript. 
Funding: The study was supported by the National Natural Science Foundation of China (81874332), the Natural Science Foundation of Hunan Province (2020JJ2012), the Scientific Research Fund of Hunan Provincial Education Department (18B387) and the Postdoctoral Science Foundation of China (2017T100601, 2016M590746).

Acknowledgments: The critical reading of the manuscript by C.T. Au, College of Materials and Chemical Engineering, Hunan Institute of Engineering is greatly appreciated.

Conflicts of Interest: The authors declare no conflict of interest.

Sample Availability: Samples of the compounds are available from the corresponding authors.

\section{References}

1. Jung, J.H.; Kim, H.Y.; Kim, H.S.; Jung, S.H. Transcriptome analysis of Panax ginseng response to high light stress. J. Ginseng Res. 2020, 44, 312-320. [CrossRef]

2. Kim, H.M.; Song, Y.; Hyun, G.H.; Long, N.P.; Park, J.H.; Hsieh, Y.S.; Kwon, S.W. Characterization and Antioxidant Activity Determination of Neutral and Acidic Polysaccharides from Panax ginseng C. A. Meyer. Molecules 2020, 25, 791. [CrossRef]

3. Nakhjavani, M.; Smith, E.; Townsend, A.R.; Price, T.J.; Hardingham, J.E. Anti-angiogenic properties of ginsenoside Rg3. Molecules 2020, 25, 4905. [CrossRef]

4. Wang, C.; Liu, J.; Deng, J.; Wang, J.; Weng, W.; Chu, H.; Meng, Q. Advances in the chemistry, pharmacological diversity, and metabolism of 20(R)-ginseng saponins. J. Ginseng Res. 2020, 44, 14-23. [CrossRef] [PubMed]

5. Chen, C.; Lv, Q.; Li, Y.; Jin, Y.-H. The Anti-Tumor Effect and Underlying Apoptotic Mechanism of Ginsenoside Rk1 and Rg5 in Human Liver Cancer Cells. Molecules 2021, 26, 3926. [CrossRef] [PubMed]

6. Ghosh, R.; Smith, S.A.; Nwangwa, E.E.; Arivett, B.A.; Bryant, D.L.; Fuller, M.L.; Hayes, D.; Bowling, J.L.; Nelson, D.E.; DuBois, J.D.; et al. Panax quinquefolius (North American ginseng) cell suspension culture as a source of bioactive polysaccharides: Immunostimulatory activity and characterization of a neutral polysaccharide AGC1. Int. J. Biol. Macromol. 2019, 139, $221-232$. [CrossRef] [PubMed]

7. Qiang, B.; Miao, J.; Phillips, N.; Wei, K.; Gao, Y. Recent advances in the tissue culture of american ginseng (Panax Quinquefoli-us). Chem. Biodivers. 2020, 17, e2000366. [CrossRef]

8. Liu, D.; Wang, X.; Lin, Y.; Chen, Z.; Xu, H.; Wang, L. The effects of cerium on the growth and some antioxidant metabolisms in rice seedlings. Environ. Sci. Pollut. Res. 2012, 19, 3282-3291. [CrossRef]

9. Zhang, C.; Li, Q.; Zhang, M.; Zhang, N.; Li, M. Effects of rare earth elements on growth and metabolism of medicinal plants. Acta Pharm. Sin. B 2013, 3, 20-24. [CrossRef]

10. Huang, G.; Shan, C. Lanthanum improves the antioxidant capacity in chloroplast of tomato seedlings through ascorbateglutathione cycle under salt stress. Sci. Hortic. 2018, 232, 264-268. [CrossRef]

11. Lu, C.; Ma, Y.; Wang, J. Lanthanum elicitation on hypocrellin A production in mycelium cultures of Shiraia bambusicola is mediated by ROS generation. J. Rare Earths 2019, 37, 895-902. [CrossRef]

12. Wang, L.; Huang, X.; Zhou, Q. Protective Effect of Rare Earth against Oxidative Stress Under Ultraviolet-B Radiation. Biol. Trace Elem. Res. 2008, 128, 82-93. [CrossRef] [PubMed]

13. Peng, Q.; Zhou, Q. Antioxidant Capacity of Flavonoid in Soybean Seedlings under the Joint Actions of Rare Earth Element La(III) and Ultraviolet-B Stress. Biol. Trace Elem. Res. 2008, 127, 69-80. [CrossRef] [PubMed]

14. Ramírez-Olvera, S.M.; Trejo-Téllez, L.I.; García-Morales, S.; Pérez-Sato, J.A.; Gómez-Merino, F.C. Cerium enhances germination and shoot growth, and alters mineral nutrient concentration in rice. PLoS ONE 2018, 13, e0194691. [CrossRef]

15. Xin, P.; Shuang-Lin, Z.; Jun-Yao, H.; Li, D. Influence of Rare Earth Elements on Metabolism and Related Enzyme Activity and Isozyme Expression in Tetrastigma hemsleyanum Cell Suspension Cultures. Biol. Trace Elem. Res. 2013, 152, 82-90. [CrossRef]

16. Xu, Y.; Zhang, G.; Wang, Y.; Guo, G. Effect of La(NO3)3 and Ce(NO3)3 on shoot induction and seedling growth of in vitro cul-tured Anoectochilus roxburghii. J. Plant Biol. 2016, 59, 105-113. [CrossRef]

17. Zhang, L.; Zeng, F.; Xiao, R. Effect of Lanthanum Ions (La3+) on the Reactive Oxygen Species Scavenging Enzymes in Wheat Leaves. Biol. Trace Elem. Res. 2003, 91, 243-252. [CrossRef]

18. Farooq, M.A.; Niazi, A.K.; Akhtar, J.; Saifullah; Farooq, M.; Souri, Z.; Karimi, N.; Rengel, Z. Acquiring control: The evolution of ROS-Induced oxidative stress and redox signaling pathways in plant stress responses. Plant Physiol. Biochem. 2019, 141, 353-369. [CrossRef]

19. Mittler, R. ROS Are Good. Trends Plant Sci. 2017, 22, 11-19. [CrossRef]

20. Yang, F.; Liu, X.; Wang, H.; Deng, R.; Yu, H.; Cheng, Z. Identification and Allelopathy of Green Garlic (Allium sativum L.) Volatiles on Scavenging of Cucumber (Cucumis sativus L.) Reactive Oxygen Species. Molecules 2019, 24, 3263. [CrossRef]

21. Sathiyaraj, G.; Lee, O.R.; Parvin, S.; Khorolragchaa, A.; Kim, Y.-J.; Yang, D.C. Transcript profiling of antioxidant genes during biotic and abiotic stresses in Panax ginseng C. A. Meyer. Mol. Biol. Rep. 2010, 38, 2761-2769. [CrossRef] [PubMed]

22. Hu, X.; Neill, S.; Cai, W.; Tang, Z. Hydrogen peroxide and jasmonic acid mediate oligogalacturonic acid-induced saponin accumulation in suspension-cultured cells of Panax ginseng. Physiol. Plant. 2003, 118, 414-421. [CrossRef] 
23. Ali, M.B.; Yu, K.-W.; Hahn, E.-J.; Paek, K.-Y. Differential responses of anti-oxidants enzymes, lipoxygenase activity, ascorbate content and the production of saponins in tissue cultured root of mountain Panax ginseng C.A. Mayer and Panax quinquefolium L. in bioreactor subjected to methyl jasmonate stress. Plant Sci. 2005, 169, 83-92. [CrossRef]

24. Ali, M.B.; Yu, K.-W.; Hahn, E.-J.; Paek, K.-Y. Methyl jasmonate and salicylic acid elicitation induces ginsenosides accumulation, enzymatic and non-enzymatic antioxidant in suspension culture Panax ginseng roots in bioreactors. Plant Cell Rep. 2006, 25, 613-620. [CrossRef]

25. Wu, C.H.; Popova, E.V.; Hahn, E.J.; Paek, K.Y. Linoleic and $\alpha$-linolenic fatty acids affect biomass and secondary metabolite production and nutritive properties of Panax ginseng adventitious roots cultured in bioreactors. Biochem. Eng. J. 2009, 47, 109-115. [CrossRef]

26. Tewari, R.K.; Hahn, E.-J.; Paek, K.-Y. Function of nitric oxide and superoxide anion in the adventitious root development and antioxidant defence in Panax ginseng. Plant Cell Rep. 2007, 27, 563-573. [CrossRef]

27. Ho, T.-T.; Murthy, H.N.; Park, S.-Y. Methyl Jasmonate Induced Oxidative Stress and Accumulation of Secondary Metabolites in Plant Cell and Organ Cultures. Int. J. Mol. Sci. 2020, 21, 716. [CrossRef]

28. Chen, S.-A.; Zhao, B.; Wang, X.; Yuan, X.; Wang, Y. Promotion of the growth of Crocus sativus cells and the production of crocin by rare earth elements. Biotechnol. Lett. 2004, 26, 27-30. [CrossRef]

29. Ouyang, J.; Wang, X.; Zhao, B.; Yuan, X.; Wang, Y. Effects of rare earth elements on the growth of Cistanche deserticola cells and the production of phenylethanoid glycosides. J. Biotechnol. 2003, 102, 129-134. [CrossRef]

30. Zicari, M.A.; D'Aquino, L.; Paradiso, A.; Mastrolitti, S.; Tommasi, F. Effect of cerium on growth and antioxidant metabolism of Lemna minor L. Ecotoxicol. Environ. Saf. 2018, 163, 536-543. [CrossRef]

31. Ma, Y.; Kuang, L.; He, X.; Bai, W.; Ding, Y.; Zhang, Z.; Zhao, Y.; Chai, Z. Effects of rare earth oxide nanoparticles on root elongation of plants. Chemosphere 2010, 78, 273-279. [CrossRef]

32. López-Moreno, M.L.; de la Rosa, G.; Hernández-Viezcas, J.Á.; Castillo-Michel, H.; Botez, C.E.; Peralta-Videa, J.R.; GardeaTorresdey, J.L. Evidence of the Differential Biotransformation and Genotoxicity of ZnO and CeO2 Nanoparticles on Soybean (Glycine max) Plants. Environ. Sci. Technol. 2010, 44, 7315-7320. [CrossRef]

33. Yin, S.; Ze, Y.; Liu, C.; Li, N.; Zhou, M.; Duan, Y.; Hong, F. Cerium Relieves the Inhibition of Nitrogen Metabolism of Spinach Caused by Magnesium Deficiency. Biol. Trace Elem. Res. 2009, 132, 247-258. [CrossRef]

34. Kim, Y.-J.; Jeon, J.-N.; Jang, M.-G.; Oh, J.Y.; Kwon, W.-S.; Jung, S.-K.; Yang, D.-C. Ginsenoside profiles and related gene expression during foliation in Panax ginseng Meyer. J. Ginseng Res. 2014, 38, 66-72. [CrossRef] [PubMed]

35. Yuan, X.; Wang, Q.; Zhao, B.; Wang, Y. Improved cell growth and total flavonoids of Saussurea medusa on solid culture medi-um supplemented with rare earth elements. Biotechnol. Lett. 2002, 24, 1889-1892. [CrossRef]

36. Yuan, Y.J.; Hu, G.W.; Wang, C.G.; Jing, Y.; Zhou, Y.Q.; Shen, P.W. Effect of La, Ce on Taxus cuspidata cell growth, biosynthesis and release of taxol. J. Rare Earths 1998, 16, 300-306.

37. Yuan, Y.-J.; Li, J.-C.; Ge, Z.-Q.; Wu, J.-C. Superoxide anion burst and taxol production induced by Ce4+ in suspension cultures of Taxus cuspidata. J. Mol. Catal. B Enzym. 2002, 18, 251-260. [CrossRef]

38. Yang, S.; Lu, S.-H.; Yuan, Y.-J. Cerium elicitor-induced phosphatidic acid triggers apoptotic signaling development in Taxus cuspidata cell suspension cultures. Chem. Phys. Lipids 2009, 159, 13-20. [CrossRef]

39. Zhao, J.; Zhu, W.; Hu, Q. Promotion of indole alkaloid production in Catharanthus roseus cell cultures by rare earth elements. Biotechnol. Lett. 2000, 22, 825-828. [CrossRef]

40. Bian, L.H.; Zou, L.; Zhou, B.Q.; Liu, W.; Zhou, J.; Wang, X. Effect of lanthanum on accumulation of activeconstituent and key enzymes expression of Salvia miltiorrhiza hairy root. China J. Chin. Mater. Med. 2016, 41, 4344-4349.

41. Li, J.; Yang, Y.; Sun, K.; Chen, Y.; Chen, X.; Li, X. Exogenous Melatonin Enhances Cold, Salt and Drought Stress Tolerance by Improving Antioxidant Defense in Tea Plant (Camellia sinensis (L.) O. Kuntze). Molecules 2019, 24, 1826. [CrossRef]

42. Li, X.; Wei, J.P.; Scott, E.R.; Liu, J.W.; Guo, S.; Li, Y.; Zhang, L.; Han, W.Y. Exogenous melatonin alleviates cold stress by pro-moting antioxidant defense and redox homeostasis in Camellia sinensis L. Molecules 2018, 23, 165. [CrossRef]

43. Xu, Q.-M.; Chen, H. Antioxidant responses of rice seedling to Ce4+ under hydroponic cultures. Ecotoxicol. Environ. Saf. 2011, 74, 1693-1699. [CrossRef]

44. Huang, S.-F.; Li, Z.-Y.; Wang, X.-Q.; Wang, Q.-X.; Hu, F.-F. Cerium caused life span shortening and oxidative stress resistance in Drosophila melanogaster. Ecotoxicol. Environ. Saf. 2010, 73, 89-93. [CrossRef] [PubMed]

45. Rico, C.M.; Morales, M.I.; McCreary, R.; Castillo-Michel, H.; Barrios, A.C.; Hong, J.; Tafoya, A.; Lee, W.-Y.; Varela-Ramirez, A.; Peralta-Videa, J.R.; et al. Cerium Oxide Nanoparticles Modify the Antioxidative Stress Enzyme Activities and Macromolecule Composition in Rice Seedlings. Environ. Sci. Technol. 2013, 47, 14110-14118. [CrossRef]

46. Chen, Y.; Luo, Y.; Qiu, N.; Hu, F.; Sheng, L.; Wang, R.; Cao, F. Ce3+ induces flavonoids accumulation by regulation of pigments, ions, chlorophyll fluorescence and antioxidant enzymes in suspension cells of Ginkgo biloba L. Plant Cell Tissue Organ Cult. 2015, 123, 283-296. [CrossRef]

47. Dias, M.C.; Mariz-Ponte, N.; Santos, C. Lead induces oxidative stress in Pisum sativum plants and changes the levels of phyto-hormones with antioxidant role. Plant Physiol. Biochem. 2019, 137, 121-129. [CrossRef] [PubMed]

48. Xu, J.; Duan, X.; Yang, J.; Beeching, J.R.; Zhang, P. Enhanced reactive oxygen species scavenging by overproduction of super-oxide dismutase and catalase delays postharvest physiological deterioration of cassava storage roots. Plant Physiol. 2013, 161, 1517-1528. [CrossRef] 
49. Wu, M.; Wang, P.-Y.; Sun, L.-G.; Zhang, J.-J.; Yu, J.; Wang, Y.-W.; Chen, G.-X. Alleviation of cadmium toxicity by cerium in rice seedlings is related to improved photosynthesis, elevated antioxidant enzymes and decreased oxidative stress. Plant Growth Regul. 2014, 74, 251-260. [CrossRef]

50. Cao, F.; Wang, N.; Zhang, M.; Dai, H.; Dawood, M.; Zhang, G.; Wu, F. Comparative study of alleviating effects of GSH, Se and Zn under combined contamination of cadmium and chromium in rice (Oryza sativa). BioMetals 2013, 26, 297-308. [CrossRef]

51. Farooq, M.A.; Ali, S.; Hameed, A.; Ishaque, W.; Mahmood, K.; Iqbal, Z. Alleviation of cadmium toxicity by silicon is related to elevated photosynthesis, antioxidant enzymes; suppressed cadmium uptake and oxidative stress in cotton. Ecotoxicol. Environ. Saf. 2013, 96, 242-249. [CrossRef] [PubMed]

52. Liu, Z.; Zhang, S.; Sun, N.; Liu, H.; Zhao, Y.; Liang, Y.; Zhang, L.; Han, Y. Functional diversity of jasmonates in rice. Rice 2015, 8, 5. [CrossRef]

53. Rahimi, S.; Kim, Y.-J.; Sukweenadhi, J.; Zhang, D.; Yang, D.-C. PgLOX6encoding a lipoxygenase contributes to jasmonic acid biosynthesis and ginsenoside production in Panax ginseng. J. Exp. Bot. 2016, 67, 6007-6019. [CrossRef] [PubMed]

54. Creelman, R.A.; Tierney, M.L.; Mullet, J.E. Jasmonic acid/methyl jasmonate accumulate in wounded soybean hypocotyls and modulate wound gene expression. Proc. Natl. Acad. Sci. USA 1992, 89, 4938-4941. [CrossRef]

55. Gundlach, H.; Müller, M.J.; Kutchan, T.M.; Zenk, M.H. Jasmonic acid is a signal transducer in elicitor-induced plant cell cul-tures. Proc. Natl. Acad. Sci. USA 1992, 89, 2389-2393. [CrossRef]

56. Wang, Y.; Yuan, G.; Yuan, S.; Duan, W.; Wang, P.; Bai, J.; Zhang, F.; Gao, S.; Zhang, L.; Zhao, C. TaOPR2 encodes a 12-oxophytodienoic acid reductase involved in the biosynthesis of jasmonic acid in wheat (Triticum aestivum L.). Biochem. Biophys. Res. Commun. 2016, 470, 233-238. [CrossRef] [PubMed]

57. Wang, B.; Niu, J.; Li, B.; Huang, Y.; Han, L.; Liu, Y.; Zhou, W.; Hu, S.; Li, L.; Wang, D.; et al. Molecular Characterization and Overexpression of SmJMT Increases the Production of Phenolic Acids in Salvia miltiorrhiza. Int. J. Mol. Sci. 2018, $19,3788$. [CrossRef]

58. Wu, J.-Y.; Ge, X. Oxidative burst, jasmonic acid biosynthesis, and taxol production induced by low-energy ultrasound in Taxus chinensis cell suspension cultures. Biotechnol. Bioeng. 2004, 85, 714-721. [CrossRef]

59. Kim, Y.J.; Zhang, D.; Yang, D.C. Biosynthesis and biotechnological production of ginsenosides. Biotechnol. Adv. 2015, 33, 717-735. [CrossRef]

60. Rahimi, S.; Balusamy, S.D.; Khorolragchaa, A.; Kim, Y.J.; Kim, J.H.; Jung, S.; Yang, D. Effect of salicylic acid and yeast ex-tract on the accumulation of jasmonic acid and sesquiterpenoids in Panax ginseng adventitious roots. Russ. J. Plant Phys. 2014, 61, 811-817. [CrossRef]

61. Liu, T.; Luo, T.; Guo, X.; Zou, X.; Zhou, D.; Afrin, S.; Li, G.; Zhang, Y.; Zhang, R.; Luo, Z. PgMYB2, a MeJA-Responsive Transcription Factor, Positively Regulates the Dammarenediol Synthase Gene Expression in Panax Ginseng. Int. J. Mol. Sci. 2019, 20, 2219. [CrossRef]

62. Choi, D.-W.; Jung, J.; Ha, Y.I.; Park, H.-W.; In, D.S.; Chung, H.-J.; Liu, J.R. Analysis of transcripts in methyl jasmonate-treated ginseng hairy roots to identify genes involved in the biosynthesis of ginsenosides and other secondary metabolites. Plant Cell Rep. 2004, 23, 557-566. [CrossRef]

63. Dai, Z.; Wang, B.; Liu, Y.; Shi, M.; Wang, D.; Zhang, X.; Liu, T.; Huang, L.; Zhang, X. Producing aglycons of ginsenosides in bakers' yeast. Sci. Rep. 2014, 4, 3698. [CrossRef]

64. Balusamy, S.R.D.; Rahimi, S.; Sukweenadhi, J.; Kim, Y.-J.; Yang, D.-C. Exogenous methyl jasmonate prevents necrosis caused by mechanical wounding and increases terpenoid biosynthesis in Panax ginseng. Plant Cell Tissue Organ Cult. 2015, 123, 341-348. [CrossRef]

65. Yang, L.; Li, J.; Ji, J.; Li, P.; Yu, L.; Allah, E.A.; Luo, Y.; Hu, L.; Hu, X. High Temperature Induces Expression of Tobacco Transcription Factor NtMYC2a to Regulate Nicotine and JA Biosynthesis. Front. Physiol. 2016, 7, 465. [CrossRef]

66. Yin, J.; Zhang, D.; Zhuang, J.; Huang, Y.; Mu, Y.; Lv, S. Study on the correlation between gene expression and enzyme activity of seven key enzymes and ginsenoside content in ginseng in over time in Ji'an, China. Int. J. Mol. Sci. 2017, 18, 2682. [CrossRef]

67. Huang, C.; Zhong, J.-J. Elicitation of ginsenoside biosynthesis in cell cultures of Panax ginseng by vanadate. Process. Biochem. 2013, 48, 1227-1234. [CrossRef]

68. Zhang, R.; Zhang, B.-L.; Li, G.-C.; Xie, T.; Hu, T.; Luo, Z.-Y. Enhancement of ginsenoside Rg1 in Panax ginseng hairy root by overexpressing the $\alpha$-1-rhamnosidase gene from Bifidobacterium breve. Biotechnol. Lett. 2015, 37, 2091-2096. [CrossRef] [PubMed]

69. Akram, N.A.; Shafiq, F.; Ashraf, M. Ascorbic acid-a potential oxidant scavenger and its role in plant development and abiotic stress tolerance. Front. Plant Sci. 2017, 8, 613. [CrossRef]

70. Rejeb, K.B.; Lefebvre-De Vos, D.; Le Disquet, I.; Leprince, A.S.; Bordenave, M.; Maldiney, R.; Jdey, A.; Abdelly, C.; Savoure, A. Hydrogen peroxide produced by NADPH oxidases increases proline accumulation during salt or mannitol stress in Arabidopsis thaliana. New Phytol. 2015, 208, 1138-1148. [CrossRef] [PubMed]

71. Baque, A.; Hahn, E.-J.; Paek, K.-Y. Growth, secondary metabolite production and antioxidant enzyme response of Morinda citrifolia adventitious root as affected by auxin and cytokinin. Plant Biotechnol. Rep. 2010, 4, 109-116. [CrossRef]

72. Zhang, R.; Tan, S.Q.; Zhang, B.L.; Guo, Z.Y.; Tian, L.Y.; Weng, P.; Luo, Z.Y. Two key amino acids variant of alpha-Larabinofuranosidase from Bacillus subtilis Str. 168 with altered activity for selective conversion ginsenoside Rc to Rd. Molecules 2021, 26, 1733. [CrossRef] [PubMed] 
73. Liang, W.; Wang, S.; Yao, L.; Wang, J.; Gao, W. Quality evaluation of Panax ginseng adventitious roots based on ginsenoside constituents, functional genes, and ferric-reducing antioxidant power. J. Food Biochem. 2019, 43, e12901. [CrossRef] [PubMed]

74. Zhang, R.; Zhu, J.; Cao, H.-Z.; An, Y.-R.; Huang, J.-J.; Chen, X.-H.; Mohammed, N.; Afrin, S.; Luo, Z.-Y. Molecular cloning and expression analysis of PDR1-like gene in ginseng subjected to salt and cold stresses or hormonal treatment. Plant Physiol. Biochem. 2013, 71, 203-211. [CrossRef] [PubMed]

75. Li, H.-X.; Xiao, Y.; Cao, L.-L.; Yan, X.; Li, C.; Shi, H.-Y.; Wang, J.-W.; Ye, Y.-H. Cerebroside C Increases Tolerance to Chilling Injury and Alters Lipid Composition in Wheat Roots. PLoS ONE 2013, 8, e73380. [CrossRef]

76. Fournier, J.; Pouénat, M.-L.; Rickauer, M.; Rabinovltch-Chable, H.; Rigaud, M.; Marie-Thérèse, E.-T. Purification and characterization of elicitor-induced lipoxygenase in tobacco cells. Plant J. 1993, 3, 63-70. [CrossRef]

77. You, C.; Zhu, H.; Xu, B.; Huang, W.; Wang, S.; Ding, Y.; Liu, Z.; Li, G.; Chen, L.; Ding, C.; et al. Effect of Removing Superior Spikelets on Grain Filling of Inferior Spikelets in Rice. Front. Plant Sci. 2016, 7, 1161. [CrossRef] 